\title{
A Permian andesitic tuff ring at Rožmitál (the Intra-Sudetic Basin, Czech Republic) - evolution from explosive to effusive and high-level intrusive activity
}

\author{
Marek AWDANKIEWICZ ${ }^{1, *}$, Honorata AWDANKIEWICZ2 ${ }^{2}$ Vladislav RAPPRICH ${ }^{3}$ and Marcela STÁRKOVÁ ${ }^{3}$ \\ 1 University of Wrocław, Institute of Geological Sciences, Department of Mineralogy and Petrology, Cybulskiego 30, 50-205 \\ Wrocław, Poland \\ 2 Polish Geological Institute - National Research Institute, Lower Silesian Branch, al. Jaworowa 19, 53-122 Wrocław, Poland \\ 3 Czech Geological Survey, Klárov 3, 11821 Praha 1, Czech Republic
}

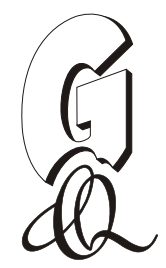

\begin{abstract}
Awdankiewicz, M., Awdankiewicz, H., Rapprich, V., Stárková, M., 2014. A Permian andesitic tuff ring at Rožmitál (the Intra-Sudetic Basin, Czech Republic) - evolution from explosive to effusive and high-level intrusive activity. Geological Quarterly, 58 (4): 759-778, doi: 10.7306/gq.1184
\end{abstract}

\begin{abstract}
Mafic, monogenetic volcanism is increasingly recognized as a common manifestation of post-collisional volcanism in late Variscan, Permo-Carboniferous intramontane basins of Central Europe. Although identification of individual eruptive centres is not easy in these ancient successions, the Permian Rožmitál andesites in the Intra-Sudetic Basin (NE Bohemian Massif) provide an exceptionally detailed record of explosive, effusive and high-level intrusive activity. Based on field study and petrographic and geochemical data on pyroclastic and coherent rocks, the Rožmitál Succession is interpreted as the proximal part of a tuff ring several hundred metres in diameter. Initial accumulation of pyroclastic fall and surge deposits occurred during phreatomagmatic eruptions, with transitions towards Strombolian eruptions. Gullies filled with reworked tephra document periods of erosion and redeposition. Andesitic blocky lavas capped the volcaniclastic succession. Invasion of lavas into unconsolidated sediments and emplacement of shallow-level intrusions in near-vent sections resulted in the formation of jigsaw- and randomly-textured peperites. Most geochemical differences between coherent andesites and pyroclastic rocks can be linked to incorporation of quartz-rich sediments during the explosive eruptive processes and to later cementation of the volcaniclastic deposits by dolomite. The Rožmitál tuff ring could have been one of several phreatomagmatic centres in a monogenetic volcanic field located on an alluvial plain.
\end{abstract}

Key words: post-collisional volcanism, andesite lavas, phreatomagmatic deposits, tuff ring, Permian, Intra-Sudetic Basin.

\section{INTRODUCTION}

Small volcanoes, such as scoria cones, tuff cones, tuff rings and maars, usually clustered in monogenetic volcanic fields, represent the most widespread volcanic centres on the Earth's land surface (e.g., Cas and Wright, 1987; Németh, 2010, and references therein). They may be also common on other Earth-type planets of the Solar System (e.g., on Mars: Brož and Hauber, 2013). Although generally characterized by relatively short and simple eruptive histories, many of these volcanoes reveal complex structures resulting from multi-stage activity, changes in eruptive styles and shifts in vent locations (e.g., Clark et al., 2009; Kereszturi and Németh, 2013, and references therein). Individual monogenetic volcanoes and their eruptions are typically small in scale (below $1 \mathrm{~km}^{3}$ ); however, the cumulative volumes of magma erupted from monogenetic volcanic fields matches that of large, polygenetic, composite

* Corresponding author, e-mail: marek.awdankiewicz@ing.uni.wroc.pl Received: April 12, 2014; accepted: May 27, 2014; first published online: July 22, 2014 volcanoes (e.g., Connor and Conway, 2000). The differences between mono- and polygenetic styles of volcanism are basically linked to episodic or more continuous rates of mantle melting and magma supply (Takada, 1994). Eruptions of mafic magmas are most common in such systems, although more evolved, andesitic to rhyolitic, or more exotic, alkaline compositions are also not rare (Connor and Conway, 2000; Davidson and Silva, 2000; Tait et al., 2009; Németh et al., 2012).

Mafic to intermediate volcanic rocks of basaltic-andesite to trachyandesite composition, usually accompanied also by silicic volcanic rocks, occur frequently within Permo-Carboniferous sequences in Europe (Fig. 1). These distinctive red-beds ("Rotliegend") and their volcano-sedimentary successions witnessed a period of large-scale extensional and wrench tectonics, basin formation and associated volcanism during the late stages of the Variscan orogeny and the following post-orogenic period (Wilson et al., 2004; McCann et al., 2006; Geissler et al., 2012, and references therein). In these ancient volcanic sequences, the former eruptive centres and vents are usually hard to identify, because erosion, tectonics and diagenetic alteration obscure key evidence and hamper detailed volcanological interpretations. On the other hand, rapid siliciclastic sedimentation and burial, characteristic for that type of post-collisional intramontane basins (e.g., Burbank and Johnson, 1983) have 


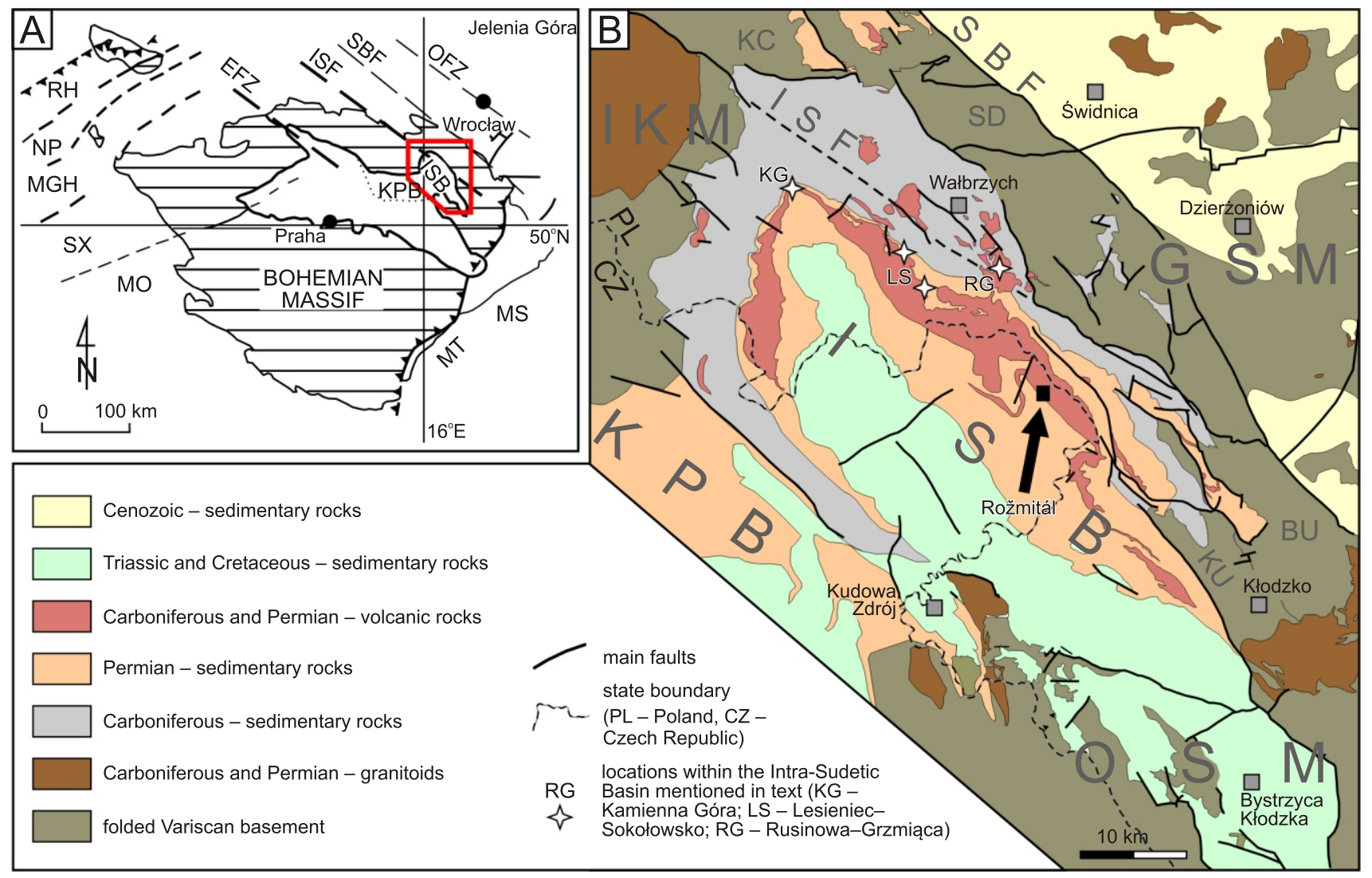

Fig. 1A - location of the Intra-Sudetic Basin (ISB) in the Bohemian Massif in the eastern part of the Variscan Belt of Europe; B - simplified geological map of the Intra-Sudetic Basin and adjacent areas (modified from Kodym et al., 1967; Bossowski et al., 1981; Sawicki, 1988; Milewicz et al., 1989)

A: EFZ - Elbe Fault Zone; ISF - Intra-Sudetic Fault; KPB - Krkonoše Piedmont Basin; MGH - Mid-German High; MO - Moldanubian Zone; MS - Moravo-Silesian Zone; MT - Moldanubian Thrust; NP - Northern Phyllite Zone; OFZ - Odra Fault Zone; RH - Rheno-Hercynian Zone; SBF - Sudetic Boundary Fault; SX - Saxo-Thuringian Zone; B: arrow points to the location of the Rožmitál quarries; BU - Bardo Unit, GSM Góry Sowie Massif, IKM - Izera-Karkonosze Massif, KC - Kaczawa Unit, KU - Kłodzko Unit, OSM - Orlica-Śnieżnik Massif, SD Świebodzice Depression

the potential to preserve spectacular volcanic landforms and structures, such as lava-domes, tuff- and pumice-cones (e.g., Geißler et al., 2008; Seghedi, 2011) or ropy structures on pahoe-hoe lavas (Stárková et al., 2011). In the eastern part of the European Variscan Belt, in the Bohemian Massif (Fig. 1), monogenetic volcanism is increasingly recognized as a common manifestation of post-collisional volcanic activity. For example, a belt of rhyolitic maars (the Rusinowa-Grzmiąca belt; Nemec, 1981; Awdankiewicz, 1999a), as well as a cluster of small trachyandesitic shield volcanoes and associated lava fields (Kamienna Góra and Lesieniec-Sokołowsko basaltic trachyandesites; Awdankiewicz, 1997, 1999a; Awdankiewicz et al., 2003) were identified in the Carboniferous and Permian deposits of the Intra-Sudetic Basin (Fig. 1), which is the biggest intramontane trough in that region. In recent years Stárková et al. (2011) recognized Hawaiian, Strombolian and phreatomagmatic eruptive products among the successions of olivine basalts to basaltic andesites of the Permian Levín Volcanic Field in the adjacent Krkonoše Piedmont Basin, west of the Intra-Sudetic Basin (Fig. 1). In the same basin, Valenta et al. (2014) discovered the Principálek volcanic structure using a geophysical survey. The Principálek volcano started its activity as a maar penetrating poorly consolidated continental deposits. Subsequent Strombolian to Hawaiian activity associated with lava effusions filled part of the maar-crater with relatively high-density mafic volcanic rocks. The various patterns of monogenetic-type volcanic activity in these basins apparently reflect the influence of both deep-seated and shallow-level controls (e.g., various magma compositions involved as well as different palaeoenvironments of eruptions including variable palaeo-hydrogeological conditions), but the present understanding of these relationships is far from satisfactory.

This paper deals with the Permian andesite succession at Rožmitál, in the central part of the Intra-Sudetic Basin, Czech Republic (Fig. 1). A wide range of lithologies with abundant volcaniclastic rocks are exceptionally well-exposed in a series of quarries. Based on detailed characterisation of several lithofacies we document variable styles of the andesitic volcanism, ranging from explosive eruptions to effusions and intrusions, with episodes of erosion and redeposition. Using bulk-rock chemical data we discuss processes that affected the composition of the pyroclastic deposits. Although the original volcano - inferred to be a tuff ring - is no longer preserved as a morphological feature, the location and characteristics of this volcanic centre are constrained by the record of its activity, the spatial relationships of various lithofacies and palaeoslope and transport direction indicators. Despite known occurrences of phreatomagmatic pyroclastic deposits, the Rožmitál quarries are, to our knowledge, the first site within the Permian basins of the Bohemian Massif where a tuff ring and related volcanogenic deposits have been documented. Our results provide a snapshot of complex volcanic processes that contribute to the formation of volcano-sedimentary successions in post-collisional, intracontinental basins. 


\section{GEOLOGICAL SETTING}

\section{THE INTRA-SUDETIC BASIN - ORIGIN AND OUTLINE OF EVOLUTION}

The Variscan collision and orogeny were amongst the major large-scale processes which contributed to the formation of the Western and Central European lithosphere in Late Paleozoic times (e.g., Ziegler and Dèzes, 2006; Mazur et al., 2006, and references therein). The following period of extensional and wrench tectonics, possibly associated with orogenic delamination (Geissler et al., 2012), resulted in the development of numerous continental sedimentary basins upon the decaying Variscan orogenic belt and its foreland. These basins accommodated thick volcano-sedimentary successions of, dominantly, siliciclastic alluvial deposits intercalated with mafic to silicic volcanic rocks during the Carboniferous and Permian (e.g., Breitkreuz and Kennedy, 1999; McCann et al., 2006; Breitkreuz et al., 2007; Timmerman, 2008; Awdankiewicz et al., 2014, and references cited there). The late- to post-collisional, widespread and voluminous Permo-Carboniferous volcanism, together with coeval granitic plutonism, originated due to orogenic delamination, mantle upwelling and melting, underplating of mantle melts, crustal anatexis, as well as extensive differentiation of the mantle melts at shallow lithospheric levels (Finger et al., 1997; Wilson et al., 2004; Ziegler and Dèzes, 2006; Mazur et al., 2007; Timmerman, 2008; Geissler et al., 2012; Oberc-Dziedzic et al., 2013a, b). The basin and range province of southwestern North America is considered a modern analogue of the Permo-Carboniferous volcanic province of Europe (Lorenz and Nicholls, 1976; Menard and Molnar, 1988).

The Intra-Sudetic Basin, situated in the northeastern part of the Bohemian Massif (Fig. 1) is a major Late Paleozoic intramontane trough in the eastern part of the European Variscan Belt, hosting the most complete record of Permo-Carboniferous sedimentation and volcanism in that region. The late- to post-orogenic succession in this basin spans the Upper Visean-Upper Saxonian/Wuchiapingian and is followed by platform-type, continental and marine, Upper Triassic and Upper Cretaceous deposits (Tásler, 1979; Dziedzic and Teisseyre, 1990; Mastalerz and Prouza, 1995). The Permo-Carboniferous deposits attain a total stratigraphic thickness of $11 \mathrm{~km}$.

The distinctive cyclic structure of the basin fill reveals a strong tectonic control on sedimentation, and the decreasing age of deposits from the north-west to the south-east can be attributed to a gradual SW-ward migration of depositional centres with time. The dominant lithologies are conglomerates, sandstones and mudstones which accumulated in alluvial fan, fluvial and lacustrine environments. Deltaic to marine intercalations are characteristic of the Visean. A shift from warm and humid, through semi-arid, to arid climate during the accumulation of the basin fill is reflected in the transition from coal-bearing, grey deposits characteristic of the Carboniferous, to red-beds typical for the latest Carboniferous and Permian (Nemec et al., 1982; Wojewoda and Mastalerz, 1989; Mastalerz and Prouza, 1995; McCann et al., 2008).

Volcanic activity accompanied sedimentation in the Carboniferous and Permian periods (Dziedzic and Teisseyre, 1990; Awdankiewicz, 1999a, b, and references therein). Recent SHRIMP zircon age determinations suggest that volcanism occurred episodically over some 30 million years between 313 and $283 \mathrm{Ma}$, culminating at ca. $290 \mathrm{Ma}$ in the Early Permian (Awdankiewicz and Kryza, 2012; Kryza and Awdankiewicz, 2012 and unpublished data). Silica-rich volcanic rocks (rhyodacites in the Carboniferous, rhyolites in the Permian) pre- dominate over intermediate-composition volcanic rocks (andesites, basaltic andesites, trachyandesites and basaltic trachyandesites). The geochemical signatures of the volcanic rocks shifts from calc-alkaline (arc-like) of the older, Carboniferous suites, towards mildly alkaline (within-plate like) of the younger, Permian eruptive rocks in the northern and central parts of the basin (Awdankiewicz, 1999a, b). The origin of magmas is linked with melting of metasomatized mantle sources followed by shallow-level differentiation dominated by fractional crystallization (Awdankiewicz, 1999a, b) or by assimilation-fractional crystallization (Dziedzic, 1998; Ulrych et al., 2004, 2006). The magmas were emplaced from several volcanic centres, including maar-type volcanoes, small trachyandesite shield volcanoes, intermediate-silicic multivent centres, and an ignimbrite-related caldera (Nemec, 1981; Awdankiewicz, 1999a, b, 2004; Awdankiewicz et al., 2003, 2013). The activity of these volcanic centres included also the emplacement of subvolcanic intrusions, preferentially in thicker sedimentary successions adjacent to intrabasinal depositional centres (Awdankiewicz, 1999a, b, 2004).

\section{GEOLOGICAL SETTING OF THE VOLCANIC SUCCESSION AT ROŽMITÁL}

In the Intra-Sudetic Basin, the extensive outcrop of Permian volcanic and volcaniclastic rocks (ca. $60 \mathrm{~km}$ from north-west to south-east, up to $700 \mathrm{~m}$ in thickness) is distinguished as the Lower Permian Volcanic Complex (Awdankiewicz, 1999a and references therein). In the local lithostratigraphic subdivision (Fig. 2) it is a part of the Słupiec Formation, equivalent to the Broumov Formation (Mastalerz and Prouza, 1995). The two names of the formation result from its outcropping across the Czech-Polish border and the various stratigraphic schemes in use. The Słupiec/Broumov Formation is included in the Lower Rotliegend (Autunian), generally corresponding to the Asselian and Sakmarian stages of the international chronostratigraphic scale (ICS, 2013). The Broumov Formation is further subdivided into the Nowa Ruda, Olivětín and Martínkovice members

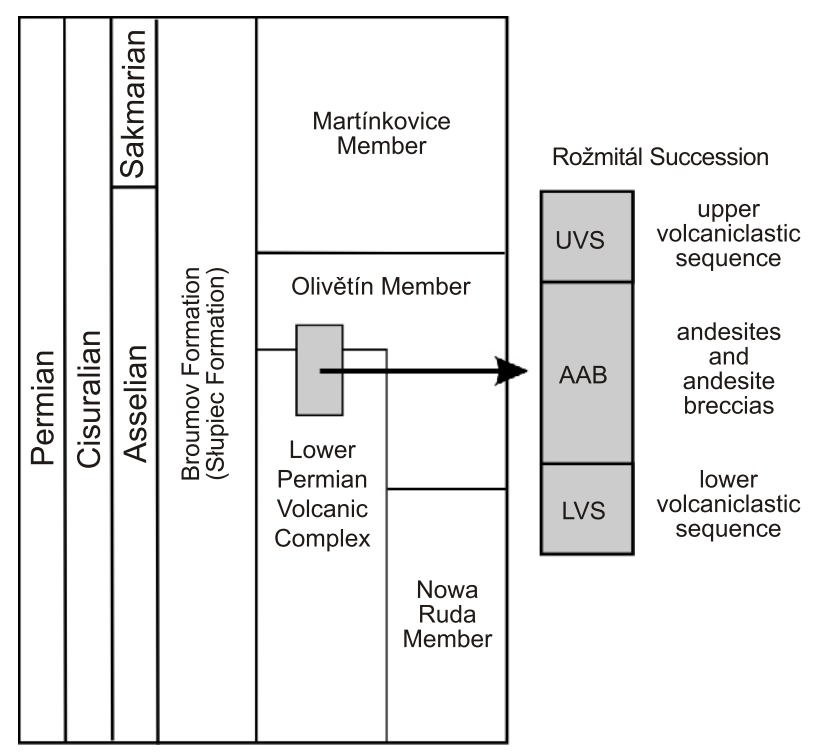

Fig. 2. Tentative lithostratigraphic scheme of the Broumov Formation in the central part of the Intra-Sudetic Basin (based on Prouza, 1988; Mastalerz and Prouza, 1995; Awdankiewicz, 1999a; Štamberg and Zajíc, 2008), together with the lithostratigraphic position and working subdivision of the "Rožmitál Succession" discussed in this paper 
(Fig. 2) in our study area located in the central part of the Intra-Sudetic Basin. The rocks discussed in this paper are part of the Olivětín Member, correspond to the uppermost part of the Lower Permian Volcanic Complex and thus are amongst the youngest eruptive products in the Intra-Sudetic Basin.

The complete thickness of the Olivětín Member exceeds $200 \mathrm{~m}$. This member comprises sandstones with subordinate conglomerates, mudstones, siltstones and limestones, intercalated with andesites as well as volcaniclastic rocks of andesitic and, less commonly, rhyolitic composition (Prouza, 1988). Sedimentation of these strata has been interpreted to represent alluvial plains with ephemeral lakes (Tásler, 1979). A transition from alluvial fan deposits to the north into lacustrine deposits to the south was recognized in the upper part of this member (Blecha, 1992).

The origin of the intermediate-composition volcanogenic rocks intercalated in the Olivětín Member has been generally linked to some local centres of volcanic activity (Fediuk and Schovánková, 1979). Neither the location, nor the types of these volcanoes have been discussed so far. Fediuk (1966) subdivided the mafic volcanic rocks of the Olivětín Member into two main horizons and several smaller, component units, tens of metres thick and several kilometres in lateral extent each. Similar units were distinguished by Prouza (1988), who classified the mafic rocks as andesites and included some of the volcaniclastic rocks into an "agglomerate unit", and others into a "volcanodetrital facies". The subject of this paper is a succession of volcanogenic rocks exposed in the Rožmitál quarries (Fig. 1 and 3). The existing subdivisions for this part of the Olivětín Member (Prouza, 1988) are considered unsatisfactory due to partly inaccurate terminology. E.g., none of the rocks at Rožmitál is an "agglomerate" - a pyroclastic rock rich in volcanic bombs (cf. Cas and Wright, 1987). Therefore, the volcanogenic sequence in the vicinity of the Rožmitál quarries is tentatively distinguished in this paper as the "Rožmitál Succession" and subdivided, from base to top, into: (1) a lower volcaniclastic sequence, (2) andesites and andesite breccias, and (3) an upper volcaniclastic sequence (Figs. 2 and 3).

\section{METHODS}

The fieldwork was carried out in 2011 and 2012. Representative samples were studied in thin sections using standard petrographic techniques. In one andesite specimen the chemical composition of minerals was determined using the electron microprobe CAMECA SX 100 at Warsaw University, Poland. In addition, mineral phases in four samples of strongly altered volcaniclastic rocks were determined by X-ray diffraction using the Siemens D 5005 diffractometer at the Institute of Geological Sciences, University of Wrocław, equipped with a Co lamp and Fe filter and using standard settings. The chemical and XRD results in this paper are only used for identification of the main mineral phases and thus are not fully reported.

Three samples of andesites from the northwesternmost quarry (quarry I, Fig. 3) were analysed in the laboratories of the Czech Geological Survey combining flame atomic absorption spectrometry (FAAS), titration, spectrophotometry and infrared-spectrometry for major oxides, X-ray fluorescence (XRF) for $\mathrm{Cr}, \mathrm{Nb}, \mathrm{Rb}, \mathrm{Zn}$ and $\mathrm{Zr}$, and inductively coupled plasma mass spectrometry (ICP-MS) for other trace elements including the rare earth elements. The samples analysed by ICP-MS were fused in $\mathrm{LiBO}_{2}$ prior to $\mathrm{HNO}_{3}$ dissolution. Detection limits are $0.01 \mathrm{wt} . \%$ for major oxides except for $\mathrm{MnO}(0.001 \mathrm{wt} \%$ ), $\mathrm{P}_{2} \mathrm{O}_{5}$ and $\mathrm{F}\left(0.005\right.$ wt. \%) and $\mathrm{H}_{2} \mathrm{O}^{+}, \mathrm{H}_{2} \mathrm{O}^{-}$and $\mathrm{CO}_{2}(0.05$ wt.\%).
Detection limits vary between $1 \mathrm{ppm}(\mathrm{Nb}$ and $\mathrm{Zr}$ ) and $2 \mathrm{ppm}(\mathrm{Cr}$, $\mathrm{Rb}$ and $\mathrm{Zn}$ ) for XRF analyses whereas for ICP-MS analyses are dependent on element and more variable (Ba, Sc, Sn 1 ppm; $\mathrm{Ni}, \mathrm{Pb}, \mathrm{Sr}, \mathrm{V} 0.5$ ppm; Nd 0.3 ppm; Rb 0.2 ppm; Ce, Cu, Ga, Hf, La, Th, U, Y 0.1 ppm; Dy, Gd, Sm, Yb 0.05 ppm; Er 0.03 ppm; Eu, Ho, Pr 0.02 ppm; Lu, Tb and Tm 0.01 ppm). The samples were carefully selected and represent fresh or only slightly altered andesites. Additionally, three samples of strongly altered pyroclastic rocks from the middle quarry (quarry II, Fig. 3) were analysed at ACME Laboratories (Vancouver, Canada) using ICP-MS and inductively coupled plasma - emission spectrometry (ICP-ES) techniques. Detection limits were $0.01 \mathrm{wt} \%$ for major elements, $0.1 \mathrm{ppm}$ for most trace elements and $0.1 \mathrm{ppm}$ $(\mathrm{La}, \mathrm{Ce})$ to $0.01 \mathrm{ppm}(\mathrm{Lu})$ for the rare earth elements.

\section{STRUCTURES AND LITHOFACIES OF THE ROŽMITÁL ANDESITES}

A geological sketch map of the vicinity of the Rožmitál quarries is shown in Figure 3A. The outcrops of volcanogenic rocks are arranged in a NNW-SSE trending belt. These rocks dip at $10-35^{\circ}$ to the SW, SSW, concordantly with the country rock succession. There are four quarries (numbered I-IV in Fig. 3) distributed along the outcrop of the andesites and andesite breccias. The NW-most quarry $(\mathrm{I})$ is the largest and the only one currently working (in 2014), whereas the SE-most quarry (IV) is the smallest and is strongly overgrown. The Rožmitál quarries expose a 50-60 m thick succession, including the lower volcaniclastic sequence (ca. $12 \mathrm{~m}$ ), followed by the andesites and andesite breccias (ca. $45 \mathrm{~m}$ ). The upper volcaniclastic sequence is not exposed there.

The following four lithofacies have been distinguished in the lower volcaniclastic sequence:

- tuffs and lapilli tuffs,

- lapillistones,

- finely laminated tuffs,

- tuffaceous breccias.

The overlying andesites and andesite breccias comprise three main lithofacies:

- coherent andesites,

- andesite breccias,

- andesitic peperites (including jigsaw-textured and randomly textured peperites).

The terminology used in the above subdivisions follows recommendations in Cas and Wright (1987) and McPhie et al. (1993). Generalized logs representing various parts of the volcanic sequence are shown in Figure 3B. Annotated photos of quarry walls in Figure 4 illustrate the distribution and spatial relationships of the lithofacies distinguished. The lower volcaniclastic sequence in quarry II comprises predominantly dark brown and locally greenish tuffs and lapilli tuffs with intercalations of lapillistones (log II in Figs. 3 and 4A). The beds are centimetres to decimetres thick (Fig. 5A). The largest clasts in the tuffs and lapilli tuffs are usually $<1 \mathrm{~cm}$ in size and indistinct normal or reverse grading occurs in some beds. The tuffs and lapilli tuffs are dominantly clast-supported but poorly sorted and predominantly consist of strongly altered glass shards as well as larger fragments of finely-vesicular scoria gradational into massive andesite clasts. Accretionary lapilli, commonly broken, are abundant in some beds. The lapillistones are distinguished by larger clasts (up to $5 \mathrm{~cm}$ ), better sorting and well-defined normal grain-size grading, especially in thicker beds. These rocks contain densely packed, ragged to angular, vesicular to mas- 

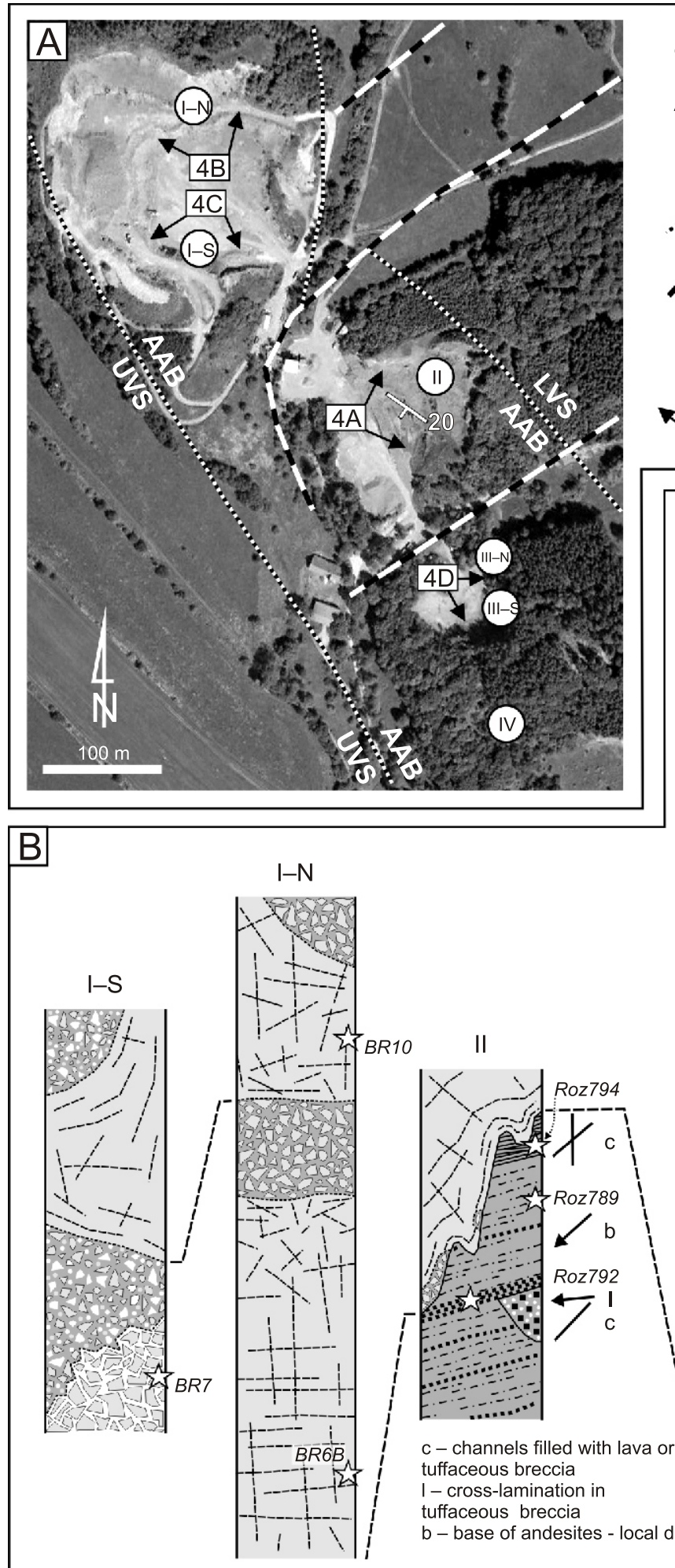

Olivětín Member, upper part - rock units

LVS - lower volcaniclastic sequence

$\mathrm{AAB}$ - andesites and andesite breccias

UVS - upper volcaniclastic sequence

..$^{+} \quad$ boundaries of lithostratigraphic units

faults

20 strike and dip of beds

(I) numbers of quarries and logs (I-N - quarry I,

photos of quarry walls shown in Figure 4

Roz792 sample for geochemistry

$\longleftarrow \quad$ directional structures

random-textured peperites

jigsaw-textured peperites

Ding andesite breccias

Conerent andesites

1.7. tuffaceous breccias

finely laminated tuffs

lanis........ lapilistones

volcaniclastic

sequence

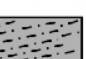

tuffs and lapilli tuffs

andesites

and andesite

breccias

III-N
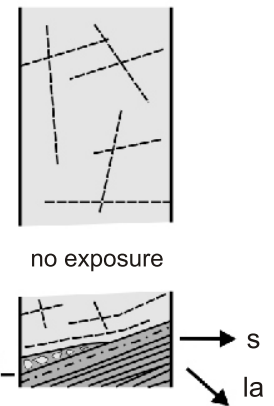

s - asymmetric impact

sag (inferred ballistic

fall direction shown)

I - cross-lamination in

uffaceous breccia

$b$ - base of andesites - local dip

low angle cross lamination

(inferred surge direction shown)

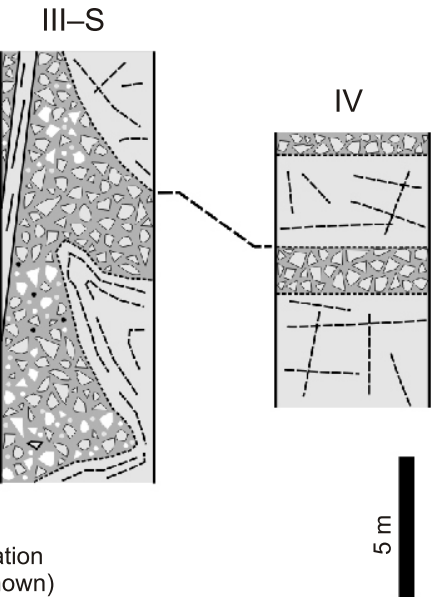

Fig. 3A - geological sketch map of the Rožmitál quarries; B - generalized logs of the volcanogenic sequence at Rožmitál

A: satellite image from GoogleEarth, acquired in 2009; rock units, geological boundaries and faults based on Prouza (1988, modified) B: locations are indicated in Figure $3 \mathrm{~A}$; the transport and other directions shown near logs II and III-N are $\pm 45^{\circ}$, without correction for the regional dip of the beds 

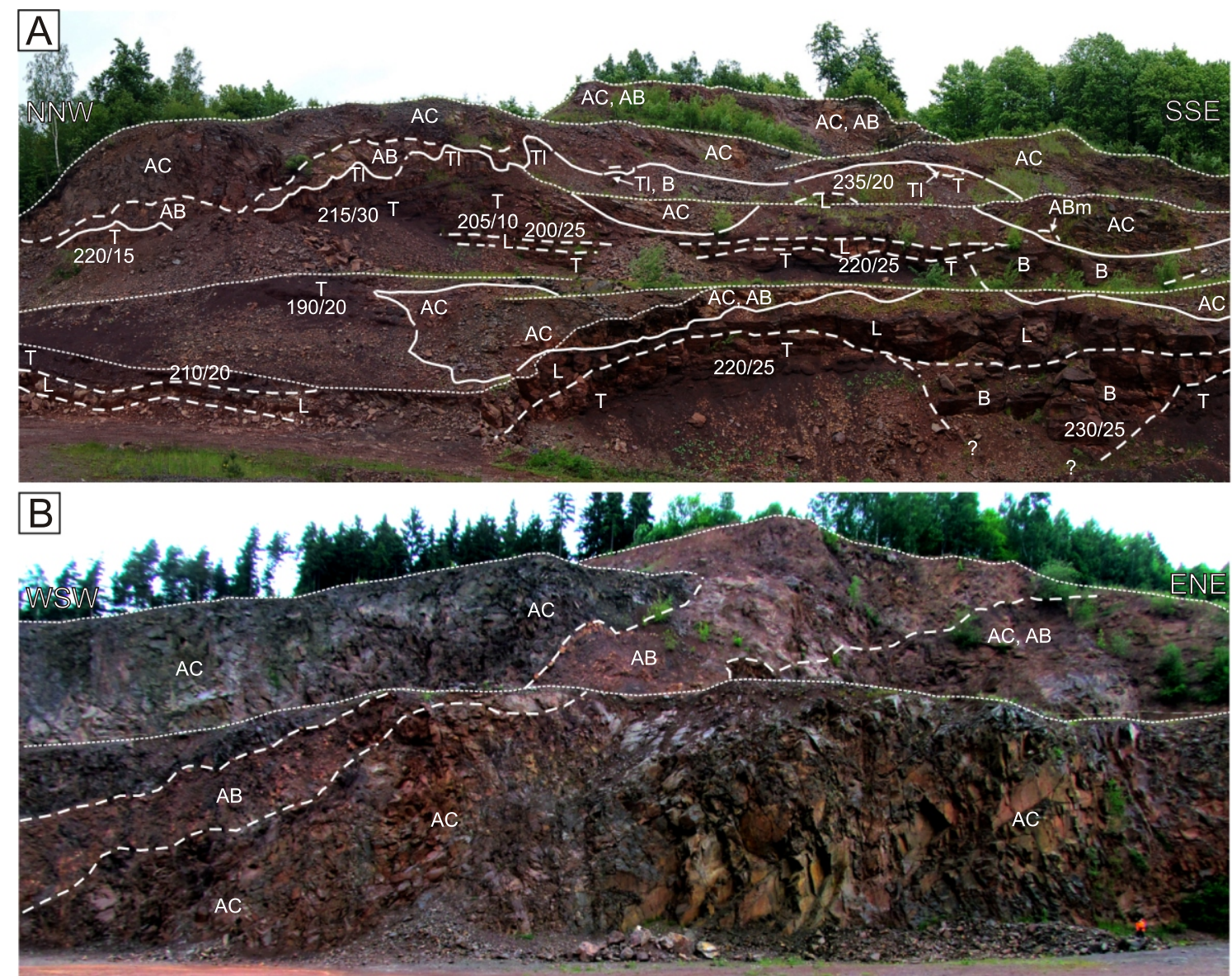

C
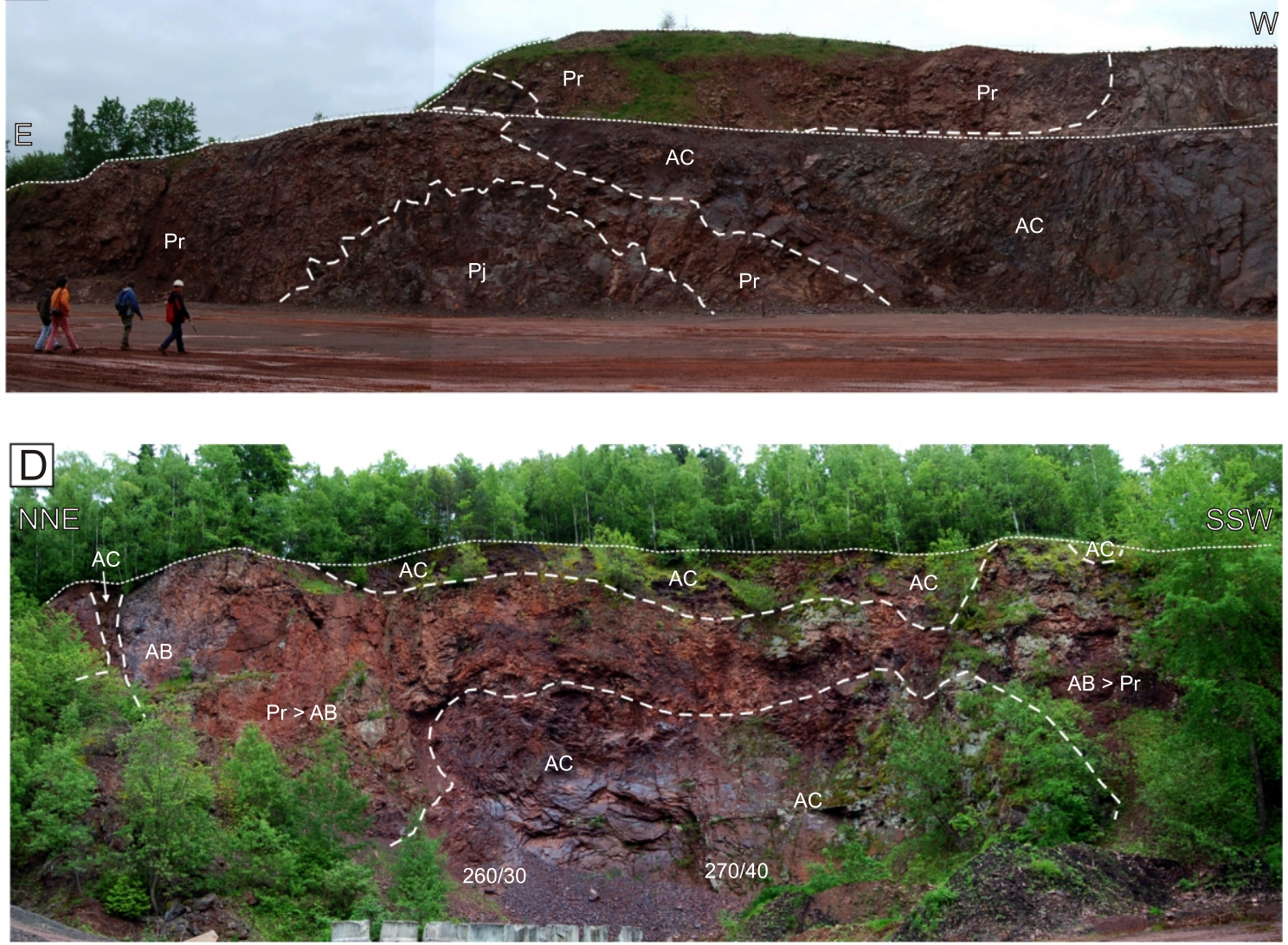

quarry walls and levels

top of the bedded

volcaniclastic sequence 、other lithological boundaries

$220 / 25$ bedding in volcaniclastic rocks 

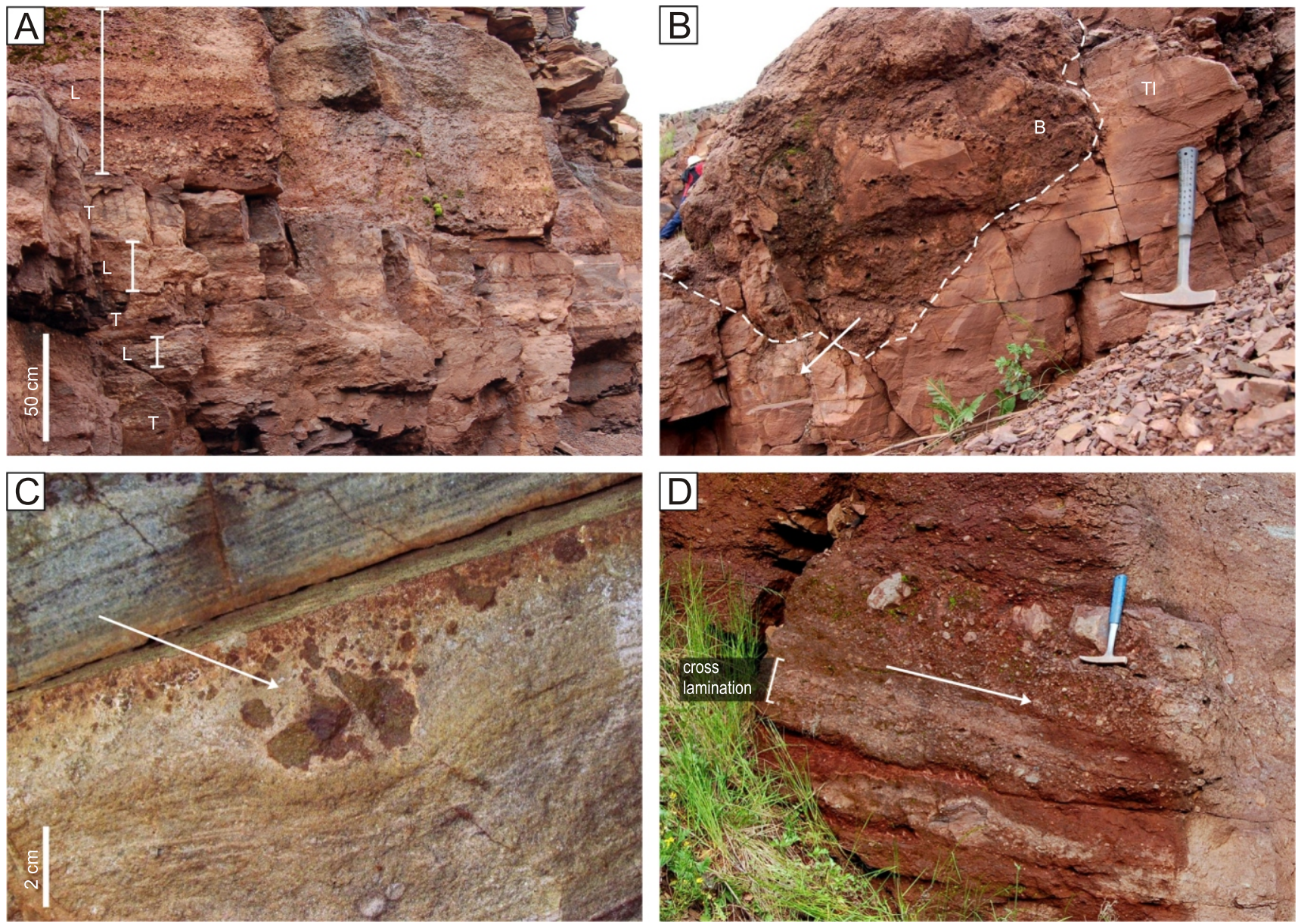

Fig. 5. The lower volcaniclastic sequence

A - the lower part of the sequence, quarry II; tuffs and lapilli tuffs $(T)$ intercalated with lapillistones $(L)$; the thickest, uppermost bed of lapillistone is distinguished as the lower marker unit and annotated L in Figure 4A; B - upper part of the sequence, quarry II (left of centre in Fig. 4A); the finely laminated tuffs (TI) distinguished as the upper marker unit, with tuffaceous breccias (B) filling a small channel cut in the finely laminated tuffs; the inferred strike of the channel (arrow) is NE-SW, roughly perpendicular to the quarry wall; C - northern part of quarry III, close-up of the finely laminated tuffs with intercalation of scoria-rich lapillistone; an asymmetrical impact sag with broken scoriaceous lapilli inside indicates fall of ballistic clasts from the west (arrow); D - tuffaceous breccia in the lower part of quarry II (lower right part in Fig. 4A); the breccia shows planar bedding and cross-lamination in finer-grained beds; the latter suggest transport of clastic material to the west (arrow)

Fig. 4. Annotated photos of quarry walls at Rožmitál

A - quarry II, the main part; the total height of the quarry is ca. $25 \mathrm{~m}$; the lower volcaniclastic sequence overlain by andesites and andesites breccias is exposed; the repetition of tuffs, lapillistones and coherent andesites in the SSE part is due to the intersection of SW-inclined beds with step-like quarry levels descending in a similar direction; B - quarry I, northern part; the total height of the quarry walls is ca. $25 \mathrm{~m}$; two sheets of SW-dipping coherent andesites are separated by andesite breccias; C - quarry I, southern part; the quarry walls are ca. $18 \mathrm{~m}$ high; in the eastern, lower part, the randomly textured peperites mantle jigsaw-textured peperites; in the western, upper part, coherent andesites wedge out within the randomly textured peperites; D - quarry III, eastern part, ca. $20 \mathrm{~m}$ high; two main bodies of coherent andesites are set in lithologically variable peperites; a thin dyke of coherent andesite (passing downwards into a larger, irregular body?) cuts the volcaniclastic rocks in the NNE. Explanations: lower volcaniclastic sequence: $\mathrm{TI}$ - finely laminated tuffs, B - tuffaceous breccias, L - lapillistones; coherent andesites and breccias: $\mathrm{Pr}$ - randomly textured peperites, $\mathrm{Pj}$ - jigsaw-textured peperites, $\mathrm{AB}$ - andesite breccias, $\mathrm{AC}$ - coherent andesites, $\mathrm{T}-$ tuffs and lapilli tuffs; location is shown in Figure $3 \mathrm{~A}$ 
sive andesite clasts. In the middle part of the bedded volcaniclastic sequence there is a characteristic ca. $80 \mathrm{~cm}$ thick bed of lapillistone (Fig. 5A, upper part) which is distinguished as the lower marker unit (marked L in Fig. 4A). In the uppermost part of the volcaniclastic sequence there is ca. $2 \mathrm{~m}$ thick intercalation of finely laminated tuffs distinguished as the upper marker unit ( $\mathrm{TI}$ in Figs. 4A and 5B). These light brown tuffs show subhorizontal and, less commonly, low-angle cross-lamination and in places contain centimetres-thick intercalations of lapilli tuffs rich in accretionary lapilli, or rich in scoria. At quarry III the low-angle cross-lamination dips to the north-west and indicates SE-ward transport of pyroclastic material by a surge, and a single observed well-defined asymmetrical impact sag (Fig. 5C) suggests fall of ballistic clasts from the west.

Two intercalations of tuffaceous breccia have been identified within the lower volcaniclastic sequence in quarry II. These tuffaceous breccias are lithologically equivalent to the tuffs and lapilli tuffs (they consist of similar andesitic clasts, with higher amounts of massive andesite blocks in the coarser fractions) but show a limited lateral extent and occur as channel-filling units within the other volcaniclastic rocks. The upper, smaller channel is cut within finely laminated tuffs of the upper marker unit (Fig. 5B). The channel is ca. $2 \mathrm{~m}$ wide, $1 \mathrm{~m}$ deep and it is NE-SW aligned. The tuffaceous breccia is weakly bedded and matrix-supported with the largest clasts up to ca. $20 \mathrm{~cm}$ long. Another, bigger channel in the lower part of the sequence occurs within the tuffs and lapilli tuffs (Fig. 4A, lower right). It is $\mathrm{NE}-\mathrm{SW}$ aligned, ca. $8 \mathrm{~m}$ wide and ca. $4 \mathrm{~m}$ deep; however, its lower part is not exposed. The fill of this channel shows some lateral variation: in the lowest level of quarry II the channel-filling tuffaceous breccia is overlain by the lapillistone of the lower marker unit (Fig. 4A), whereas farther east (on the higher level of the quarry) the lower marker horizon wedges out within the tuffaceous breccia of the channel-fill, and the latter is overlain by coherent andesites. The tuffaceous breccia in this channel is well-bedded. Some thicker beds are matrix-supported with angular andesite clasts up to $20 \mathrm{~cm}$ long enclosed in a tuffaceous matrix, whereas the thinner beds are finer-grained, better sorted and clast-supported. Westwardly dipping cross-lamination occurs in one finer-grained bed (Fig. 5D). The lithology, texture and lamination of this deposit suggest transport of clastic material by water flowing to the west.

In quarry II the lower volcaniclastic sequence is overlain by coherent andesites with a discontinuous layer of andesite breccias at the base (Fig. 4A). In the lower central part of this quarry, the andesites with breccias rest upon the lapillistone of the lower marker unit, whereas in the northern part of quarry II (and also in the northern part of quarry III - log III-N, Fig. 3), the andesites overlie the finely laminated tuffs of the upper marker unit, 5-6 $\mathrm{m}$ up-sequence. These relationships show that the base of the andesites is unconformable and cuts various levels of the lower volcaniclastic sequence. In addition, in quarry II the sharp contact surface of the bedded tuffs and the andesites is locally rough, with troughs and ridges up to 5-6 $\mathrm{m}$ wide and 2-3 $\mathrm{m}$ deep/high (Figs. 4A and 6A). The alignment of the troughs and ridges, inferred from their intersection with quarry walls, is close to $\mathrm{N}-\mathrm{S}$.

The andesites and associated breccias crop out extensively in quarries I, III and IV. Two sheets of coherent andesites, over 30 and $20 \mathrm{~m}$ thick in upward succession, separated by andesite breccias, are exposed in the northern half of quarry I ( $\log \mathrm{I}-\mathrm{N}$ in Figs. 3B and 4B). The coherent andesites are relatively densely fractured. In the lower sheet there are tabular joints gently inclined to the south-west, parallel to the top and, presumably, the base of the andesite sheet. There are also steeply inclined to subvertical joints, roughly perpendicular to the margins of the andesite sheet. Joints in the upper coherent andesite are more irregular. The boundaries between the coherent andesites and the andesite breccias are planar and sharp to gradational over short distances (ca. $1 \mathrm{~m}$ ). The andesite breccias are ca. $5 \mathrm{~m}$ thick in the WSW part of this section, but their thickness increases eastwards to $10-15 \mathrm{~m}$, where the upper coherent andesites wedge out. The breccias (Fig. 6B) are monomict and comprise isometric to elongate, angular to subrounded blocks of vesicular to massive andesite, usually less than $0.5 \mathrm{~m}$ in diameter, set in similar but finer-grained, strongly altered material. The overall fabric of the breccias is chaotic and predominantly clast-supported, but with poor sorting.

Sharing a similar overall structure, the section in the southern half of quarry I is lithologically different (log I-S in Figs. 3B and $4 \mathrm{C}$ ). The lower, eastern part comprises texturally variable andesitic peperites. In the core there is a dome-like zone, 15-20 m wide, of jigsaw-textured peperite. This peperite (Fig. 6C) consists of angular, isometric to elongated blocks of vesicular andesite, from tens of centimetres to over 1 metre in size, separated by zones and angular pockets of sandstones (to mudstones), centimetric to decimetric in size. Adjacent andesite blocks show only small displacements and a jigsaw fit, with spaces in between filled with greenish to reddish, fine-grained sandstone. Adjacent sandstone domains show a similar dip of lamination. The jigsaw-textured peperite is mantled by randomly textured peperite, 15 to $5 \mathrm{~m}$ thick in the east and west, respectively (Fig. 4C). The randomly textured peperite (Fig. 6D) consist of vesicular to massive andesite clasts, up to a few tens of centimetres in size, separated by veins and pockets of reddish to greenish sandstone and mudstone with smaller andesite fragments. The andesite fragments are subangular to subrounded and, in sediment-rich domains, irregular with lobate outlines. The sedimentary domains are massive to poorly laminated. The overall fabric is chaotic.

The upper, western part of the southern section in quarry I (Fig. 4C), comprises coherent andesites mantled by randomly textured peperites. The coherent andesites are ca. 5-20 m thick and are structurally similar to the upper coherent andesite in the northern part of quarry I. Contacts with the peperites are sharp and planar to wavy.

The boundary zone between the northern and southern sections in quarry I is not well-exposed. Possibly, there is a lateral transition from the lower coherent andesite to the north into the jigsaw-textured peperite to the south; a similar transition from the andesite breccia into the randomly textured peperite; and a continuity of the upper coherent andesite sheet. However, the two sections may also be (partly?) separated by a west-east fault.

Coherent andesites associated with peperites and andesite breccias are exposed in quarry III (log III-S in Figs. 3B and 4D). The randomly textured peperites predominate in the northern part of this quarry. However, locally they pass into variable andesite breccias, e.g., composed of tightly spaced and aligned andesite plates, or composed of massive to vesicular andesite blocks set in coherent, vesicular andesite. In the north-east, a southerly dipping $\left(165 / 75^{\circ}\right)$ coherent andesite dyke ca. $1 \mathrm{~m}$ thick cuts these breccias but downwards possibly passes into a larger body of coherent andesite. In the central part of quarry III there are two bodies of coherent andesite separated by 4-8 $\mathrm{m}$ thick andesite breccias and peperites. The lower coherent andesite shows well-developed platy joints, mostly with easterly dips $\left(265 / 35^{\circ}\right)$, but locally folded. This coherent andesite may represent an eastern remnant of a larger body originally occupying the present quarry III, or it is an inclined, platy-jointed dyke within breccias. The upper coherent andesite represents a subhorizontal, partly irregular sheet. Both coherent andesite 

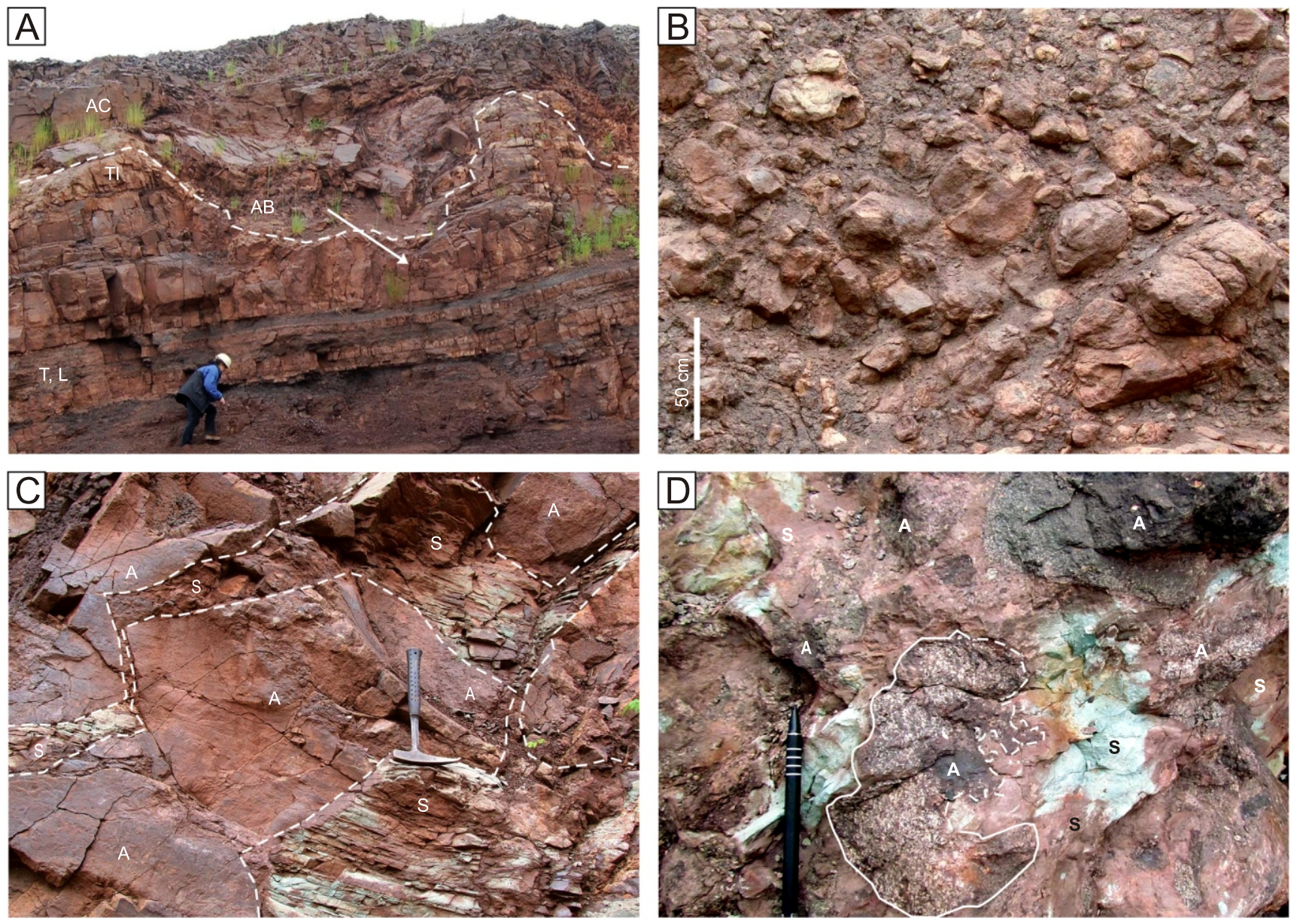

Fig. 6. The andesites with associated breccias and peperites

A - at quarry II, the coherent andesites (AC) and andesite breccias (AB), respectively, overlie a rough surface of the bedded volcaniclastic sequence ( $T, L, T I$ - tuffs and lapilli tuffs, lapillistones and finely laminated tuffs, respectively) marked by N-S aligned (arrow) troughs and ridges; the wavy arrangement of platy joints in the coherent andesites highlights the shape of the contact surface; $\mathbf{B}$ - close-up of andesite breccia at quarry I; the breccia comprises angular to surrounded clasts of vesicular andesites in a matrix of similar, but smaller and strongly altered fragments; $\mathbf{C}$-jigsaw-textured peperite at quarry I (A - andesite, $\mathrm{S}$ - sandstone); note the good fit between large andesite blocks and similar orientation of lamination in adjacent sandstone domains; D - randomly textured peperite in quarry III; angular and subrounded to lobate fragments of vesicular andesite (A) are set in a sandstone matrix (S) with dispersed smaller andesite clasts

bodies wedge out SE-wards, passing into a thicker accumulation of andesite breccias with less common peperites. However, further south, in quarry IV, a relatively thin section (ca. $12 \mathrm{~m}$ ) again exposes two sheets of coherent andesite interstratified with andesite breccias (log IV, Fig. 3B).

\section{PETROGRAPHIC CHARACTERISTICS OF THE VOLCANOGENIC ROCKS}

All the volcaniclastic rocks at Rožmitál quarries are strongly altered. The primary igneous components, such as glass, pyroxene, plagioclase, are replaced by various assemblages of secondary minerals. X-ray diffraction confirms the presence of predominating quartz and albite, with variable amounts of hematite, dolomite, calcite and clay minerals (mainly kaolinite?). Minor sanidine occurs in the finely laminated tuffs. Despite alteration, the textures are relatively well-preserved and the original fragments are usually well-defined.

The tuffs and lapilli tuffs (Fig. 7A) consist of texturally variable andesitic clasts. Vesicular glass shards (glass replaced by carbonates and quartz) and small scoria fragments predominate, but the finest fractions are recrystallized into an almost opaque, hematite-stained, microcrystalline aggregate (Fig. 7E). More massive fragments with blocky shapes are common in the coarser fractions. Some massive andesite clasts show perlitic and porphyritic textures with albitized plagioclase microphenocrysts. Accretionary lapilli and fragments of broken accretionary lapilli are locally abundant (Fig. 7B). Some accretionary lapilli are armoured, with relatively coarse lithic fragments in their cores. In some specimens lapilli-sized andesite clasts show thin coatings of recrystallized very fine ash material, similar to the margins of accretionary lapilli. Angular fragments of quartz crystals, typically $0.1-0.7 \mathrm{~mm}$ in size, are a distinctive though minor component of the tuffs. Rarely, larger quartz crystals, ca. $1 \mathrm{~mm}$ long, show rounded edges and embayments.

The lapillistones (Fig. 7C, F) are distinguished by densely packed clasts up to a few $\mathrm{cm}$ in size. The clasts are isometric to elongated, angular to irregular in shape and range from microvesicular scoria to relatively massive, microcrystalline andesite. Glass is replaced by micro- to cryptocrystalline intergrowths of feldspars, quartz and clay minerals. Some andesite fragments contain phenocrysts and microliths of albitized 

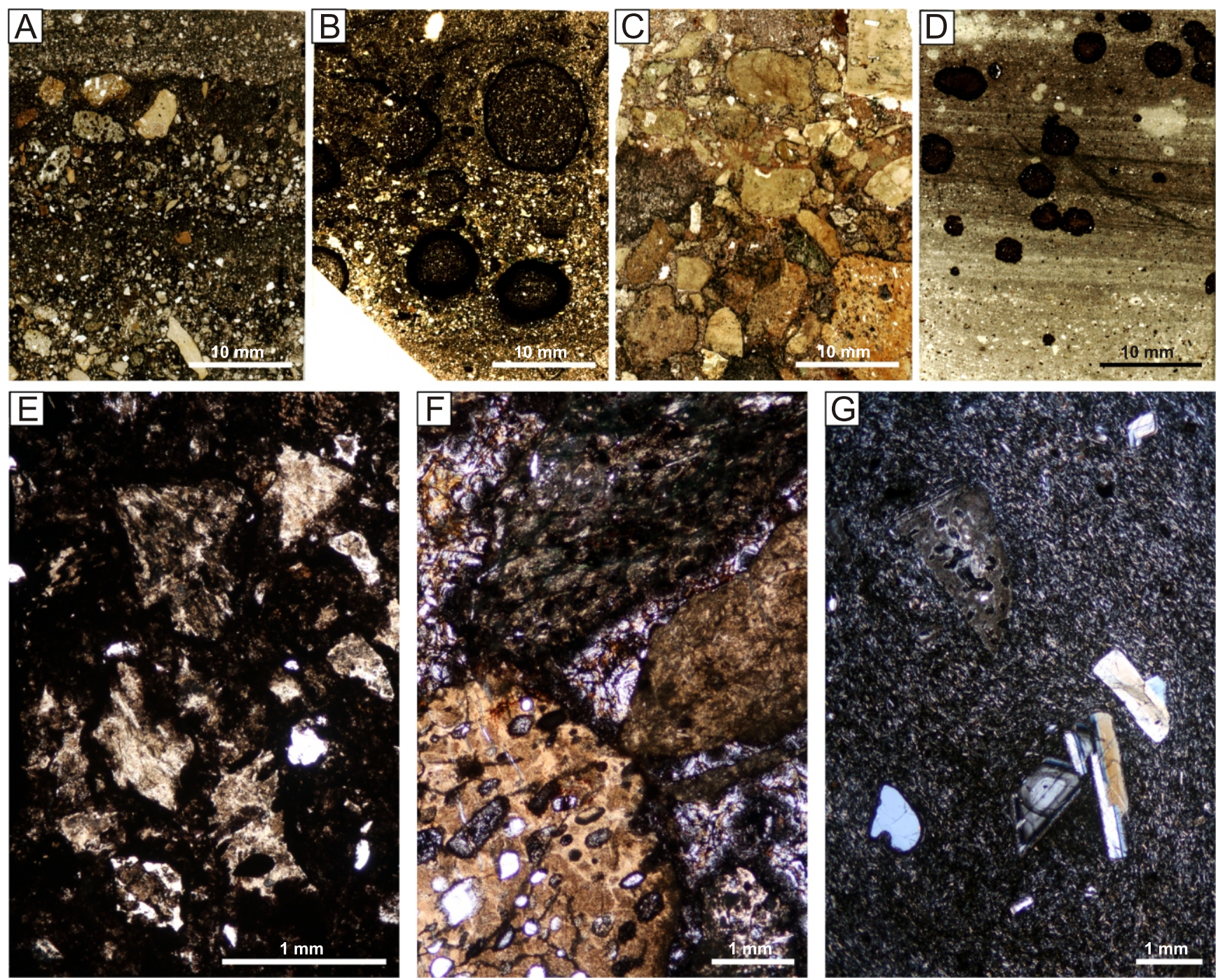

Fig. 7. Scanned thin sections (A-D) and photomicrographs (E, F- plane-polarized light;

$\mathbf{G}$ - crossed polarizers) of the volcaniclastic rocks and the andesites

A - interbedded laminae of tuff and lapilli tuff; B - lapilli tuff rich in accretionary lapilli, some of which are broken; C - lapillistone with compact fabric, composed of massive to vesicular, hypo- to microcrystalline andesite clasts; D - finely laminated tuff; the round, light and dark spots (some resembling accretionary lapilli) are diagenetic features superimposed on lamination; $\mathbf{E}-$ andesite tuff, the same section as in 7A, close-up of fine-grained fraction; the larger, vesicular, originally glassy shards are replaced by carbonates and clay minerals; abundant Fe-oxides/hydroxides obscure textures in the finest fractions; $\mathbf{F}$ - lapillistone, the same thin section as in 7C; altered, hypocrystalline, vesicular to massive andesite clasts are cemented by abundant carbonates (dolomite, minor calcite); $\mathbf{G}$ - coherent andesite from quarry II; this porphyritic rock contains a heterogeneous assemblage of plagioclase phenocrysts, including euhedral, homogeneous and zoned crystals (lower right), as well as strongly resorbed, sieve-textured crystals (upper left); a corroded, embayed quartz xenocryst at lower left; the microcrystalline groundmass consists mainly of plagioclase laths, anhedral clinopyroxene and opaques

plagioclase or show relics of spherulitic and perlitic textures. The andesitic clasts are cemented by hematite-stained carbonate aggregates, mostly dolomite and less abundant calcite. In the matrix there are also small amounts of angular quartz grains, usually $0.1-0.2 \mathrm{~mm}$ in size.

The finely laminated tuffs (Fig. 7D) show an indistinct vitroclastic texture overprinted by alteration and recrystallization. In places larger fragments of vesicular glass replaced by carbonates are relatively well seen in a matrix of microcrystalline quartz, feldspars, clay minerals and carbonates, where outlines of platy, curved, or bubble-wall shards can be partly discerned. Opaque-rich, dark clasts of microcrystalline andesite, as well as broken quartz phenocrysts, are locally visible. In some specimens of laminated tuff there are oval spots and nodules, either pale (hematite-free) or dark (hematite-rich). Some of the dark ones are accretionary lapilli, but most others are diagenetic concretions superimposed on lamination.

The tuffaceous breccias are petrographically equivalent to the tuffs and lapilli tuffs.

The coherent andesites (Fig. 7G) are porphyritic and contain $5-10 \%$ of phenocrysts up to $5 \mathrm{~mm}$ long in a microcrystalline to hypocrystalline groundmass. The phenocrysts are plagioclase (andesine) and less commonly clinopyroxene (augite). The plagioclase phenocrysts are texturally variable: euhedral to anhedral, often zoned, with embayments and variably developed sieve-textures. There are also rounded and embayed xenocrysts of alkali feldspars and quartz, the latter with reaction coronas of clinopyroxene. The groundmass con- 
sists mainly of plagioclase (labradorite, andesine) with less abundant clinopyroxenes (augite and pigeonite), opaques (ilmenite) as well as interstitial quartz, alkali feldspar, minor biotite and magnesiohornblende. In some specimens there is well-preserved interstitial, optically isotropic glass. More commonly, the andesites show variable replacement of glass and pyroxenes by calcite, dolomite and chlorite.

Andesite fragments in the breccias and peperites are strongly altered. Plagioclase is replaced by albite and kaolinite, whereas pyroxenes and glass are replaced by dark, microcrystalline mineral aggregates rich in hematite. The altered andesites contain also small patches and veins rich in quartz. The sedimentary component in the peperites comprises mainly detrital quartz grains, sericite and variable amounts of carbonates and hematite.

\section{BULK-ROCK GEOCHEMISTRY}

All the coherent andesites documented in the Rožmitál quarries (Appendix $1^{*}$ ) fall within a narrow compositional span. The andesitic petrography is in agreement with $\mathrm{SiO}_{2}$ concentrations ranging between $58.2-58.4$ wt.\%, total alkalis 5.09-5.81 wt. \% and MgO 2.6-3.2 wt.\%. The coherent samples plot in andesite field in the TAS diagram (Fig. 8A) and at the boundary between trachyandesite and andesite fields in the $\mathrm{Nb} / \mathrm{Y}$ vs. Zr/Ti diagram (Fig. 8B). Chondrite-normalized REE patterns (Fig. 8C) are gently inclined with LREE slightly enriched over HREE $\left(\mathrm{La}_{N} / \mathrm{Yb}_{\mathrm{N}}=9.75-10.5\right)$ and with a relatively weak Eu-anomaly (Eu/Eu* ca. 0.7$)$.

The volcaniclastic rocks differ significantly from coherent andesites in major oxide concentrations. The major oxide composition determined in the lapillistone is suggestive of a more basic composition (40.9 wt. \% $\mathrm{SiO}_{2}, 7.45$ wt. $\% \mathrm{MgO}$ and $13.2 \mathrm{wt} . \%$ $\mathrm{CaO}$ ), but with an extremely high content of volatiles ( $\mathrm{LOI}=$ 20 wt.\%!). Silica content shifts from the ultrabasic to basic range after recalculation on volatile-free basis. However, the ultrabasic/basic composition is inconsistent with low contents of compatible elements (e.g., $\mathrm{Cr} 9 \mathrm{ppm}$ and $\mathrm{Ni} 6 \mathrm{ppm}$ ). In several major element diagrams (Fig. 9A, B) such as $\mathrm{SiO}_{2}$ vs. $\mathrm{MgO}$, $\mathrm{Na}_{2} \mathrm{O}$ or $\mathrm{CaO}$ (the latter not shown) this rock plots on a line between coherent andesites and dolomite composition - the high $\mathrm{MgO}$ and LOI are consistent with the abundant presence of dolomite confirmed by petrography and X-ray diffraction. Overall, trace element concentrations and ratios in the lapillistone are variable: some features link this rock to coherent lavas, e.g., the $\mathrm{Nb} / Y$ ratio and the heavy- to middle-REE pattern, whereas other characteristics, such as the lower concentrations of the light $\mathrm{REE}$, less pronounced light REE enrichment and lower $\mathrm{Zr} / \mathrm{Ti}$ ratio (Fig. 8B, C) are different from those of the coherent lavas.

Two other tuff samples are characterized by high $\mathrm{SiO}_{2}$ contents (74 and $76.2 \mathrm{wt} . \%$ ) and plot in the rhyolite field in the TAS diagram (Fig. 8A). In several major element diagrams, such as $\mathrm{SiO}_{2}$ vs. $\mathrm{MgO}$ or $\mathrm{Na}_{2} \mathrm{O}$ (e.g., Fig. 9A, B) these samples plot between coherent andesites and pure quartz composition, which is consistent with moderately abundant quartz confirmed in thin sections and by XRD analysis. Other major and trace element characteristics are variable. The lapilli tuff (rich in accretionary lapilli) has contents of $\mathrm{MgO}$ (1.9 wt.\%), Ni (14 ppm), Nb (20 ppm) and $V(49 \mathrm{ppm})$ close to those of the coherent andesites, and in the $\mathrm{Nb} / \mathrm{Y}$ vs. $\mathrm{Zr} / \mathrm{Ti}$ diagram (Fig. $8 \mathrm{~B}$ ) plots close to the andesites, with a slightly lower $\mathrm{Nb} / \mathrm{Y}$ ratio. Its chondrite-normalized REE pattern (Fig. $8 \mathrm{C}$ ) is also similar to that of the coherent andesites, differing in generally lower REE contents and in a weaker enrichment in the LREE $\left(\mathrm{La}_{N} / \mathrm{Yb}_{\mathrm{N}}=\right.$ 5.33 compared to $9.75-10.5$ in the coherent andesites). However, the finely laminated tuff shows a more distinct composition with an even lower $\mathrm{Nb} / \mathrm{Y}$ ratio (0.287), decreased $\mathrm{TiO}_{2}$ (0.51 wt.\%), $\mathrm{MgO}$ (0.9 wt.\%) and $\mathrm{Ni}(8 \mathrm{ppm})$ contents, a gently inclined REE pattern $\left(\mathrm{La}_{N} / \mathrm{Yb}_{\mathrm{N}}\right.$ only 3.9$)$ and a more pronounced Eu anomaly $\left(E u / E u^{*}=0.61\right)$. Compared to the coherent andesites this tuff is enriched in HREE with a slightly "U-shaped" pattern between Tb and Er.

In Figures 8 and 9 the volcanogenic rocks were plotted together with arkoses, siltstones and limestones from the country rocks, to check the possible presence of sedimentary components in the volcaniclastic rocks (e.g., related to sediment incorporation during eruption). Overall, these volcaniclastic and sedimentary rocks are generally different in terms of major element compositions (e.g., Figs. 8A and 9A, B). However, some trace element ratios (e.g., $\mathrm{Zr} / \mathrm{Ti}, \mathrm{Nb} / \mathrm{Y}, \mathrm{Ce} / \mathrm{Yb}$ ) and contents (e.g., $\mathrm{Ga}$, $\mathrm{Yb}, \mathrm{Sr}$ ) in the volcaniclastic rocks are similar to those in arkoses and siltstones and different from those in the limestones (Fig. 9C, D). The finely laminated tuff shows some specific characteristics, such as high contents of heavy REE and a relatively weak enrichment in light REE, distinct from all other rocks (Fig. 9D).

\section{DISCUSSION}

ERUPTIVE AND DEPOSITIONAL PROCESSES OF THE LOWER VOLCANICLASTIC SEQUENCE

Considering the geological context and, in particular, the palaeogeographic reconstruction for the Olivětín Member (Blecha, 1992, Fig. 5 therein), the section at the Rožmitál quarries discussed in the present paper may represent a succession accumulated on an alluvial plain and/or a shallow, near-shore part of a lake. However, deposits indicative of subaqueous emplacement and depositional processes (e.g., pillow lavas, hyaloclastites, subaqueously reworked deposits) were not discerned at Rožmitál quarries. This suggests that the Rožmitál Succession formed in a subaerial setting.

The lower volcaniclastic sequence at Rožmitál consists predominantly of pyroclastic rocks (tuffs, lapilli tuffs and lapillistones) with intercalations of reworked pyroclastic deposits (tuffaceous breccias). Differences in structures and textural characteristics of these deposits reflect the various eruptive and depositional processes involved. Such features of the tuffs and lapilli tuffs as the relatively fine grain-size (compared to the lapillistones), abundant accretionary lapilli and ash-coated andesitic clasts, and the admixture of angular fragments of quartz crystals point to an efficient fragmentation mechanism, formation of vapour-saturated eruption clouds, aggregation of fine ash particles and incorporation of accidental detrital material into juvenile tephra. These characteristics are consistent with phreatomagmatic fragmentation and eruption mechanisms, due to magma - water/wet sediment interactions; however, the association of both strongly vesicular and more massive pyroclasts indicates also that expansion of magmatic volatiles contributed to the eruptive processes (Morrisey et al., 2000). The planar bedding, relatively poor sorting (compared to the lapillistones; Fig. 7A-C) and the locally present grain-size 

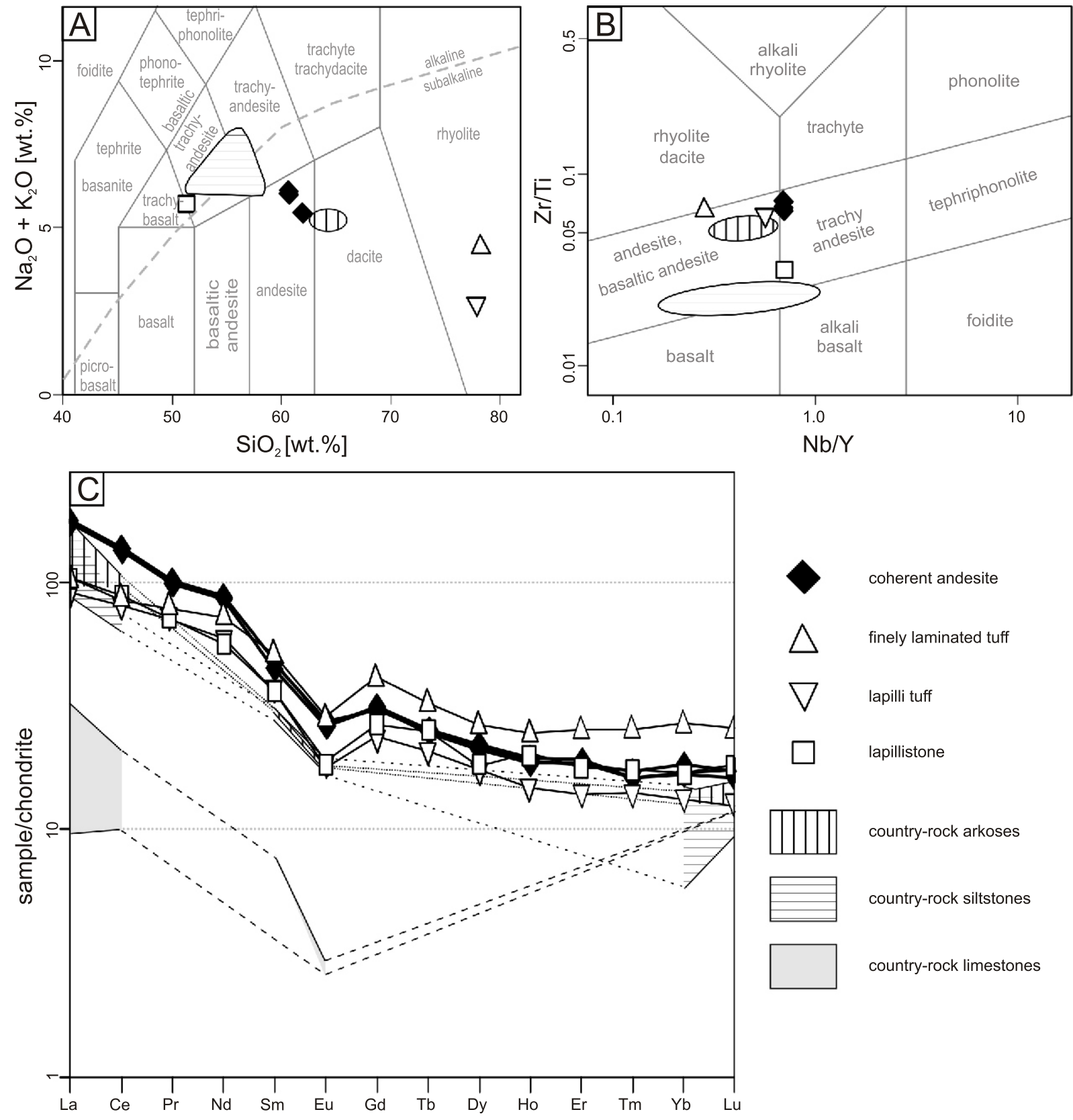

Fig. 8. Geochemical classification and rare earth element patterns of the rocks analysed

A - the TAS diagram (Bas et al., 1986); B - Nb/Y vs. Zr/Ti diagram (Pearce, 1996); C - chondrite-normalized spider plot (Boynton, 1984), country-rock sedimentary deposits plotted for comparison (from Čadková et al., 1985)

grading are suggestive of tephra deposition by a combination of pyroclastic fall and surge processes (e.g., Cas and Wright, 1987). Overall, the characteristics discussed suggest formation of the tuffs and lapilli tuffs during phreatomagmatic eruptions, possibly in rapid series of phreatomagmatic explosions generating transient eruption clouds and related pyroclastic fall and surge deposits (cf. Houghton et al., 2000).

The intercalations of lapillistones are partly different from the tuffs and lapilli tuffs in texture and types of pyroclastic fragments. The clast-supported fabric is consistent with deposition by pyroclastic fall. The much better sorting, compared with the tuffs and lapilli tuffs, may reflect relatively dry eruption clouds, as well as more effective fractionation of lapilli and ash during their fall from more sustained eruption columns (Houghton et al., 2000). The abundance of micro-vesicular fragments with irregular outlines (typical of scoria ejected during Strombolian-type eruptions) with less common non-vesicular, more angular fragments of hypocrystalline lava (indicative of quench-related fragmentation due to magma-water interaction) could be interpreted as a result of volcanic eruption driven dominantly by magmatic gas with a lesser influence of magma-water interaction. Such pulses should be classified as transitional between phreatomagmatic and Strombolian (e.g., Clarke et al., 2009), resulting from a weaker water supply to the eruption site. Strombolian-style eruptions often become dominant in later stages of activity of phreatomagmatic centres (e.g., Kereszturi and Németh, 2011; Agustín-Flores et al., 2014). 

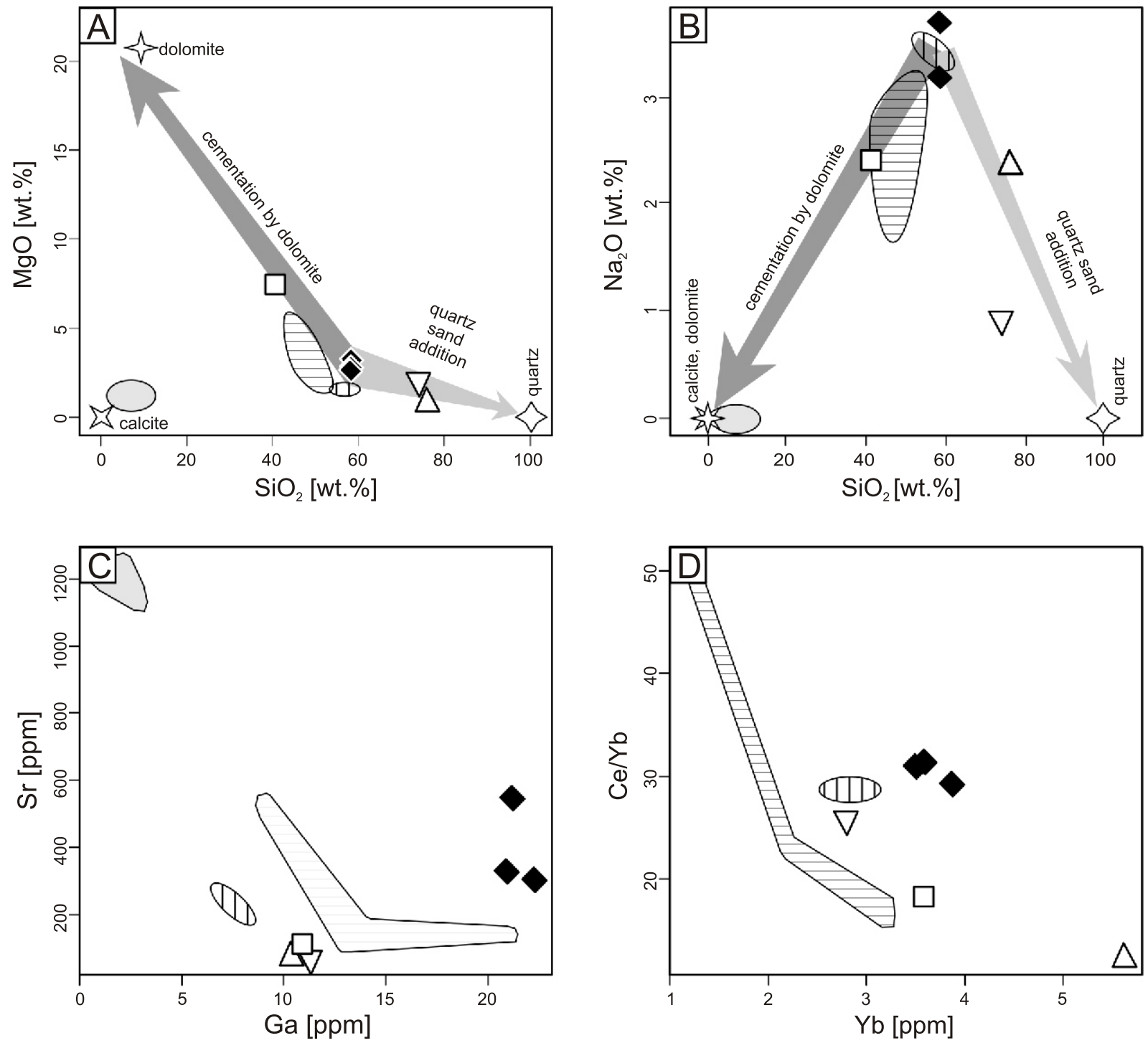

Fig. 9. Binary diagrams for selected major and trace elements (A-D) comparing andesites, pyroclastic deposits and country-rock sedimentary deposits (from Čadková et al., 1985)

In addition, ideal compositions of dolomite, calcite and quartz are plotted together with possible trends of geochemical changes in the pyroclastic rocks (discussion in text); data plotted without recalculation on a volatile-free basis; symbols as in Figure 8

The finely laminated tuffs reflect a distinctive eruptive and depositional event. The very fine grain-size suggests phreatomagmatic fragmentation and eruptive style, whereas the subhorizontal and low-angle cross-lamination indicate deposition by pyroclastic surges, possibly hot and dry base-surges (cf. Valentine and Fisher, 2000). However, thin intercalations of lapillistone rich in scoria may reflect some fluctuations of the eruption style towards Strombolian-type eruptions, with related fall-out deposition. Alternatively, these intercalations may also have been linked with such processes as density segregation of clasts or elutriation during pulsating surge-generating explosive events (e.g., Chough and Sohn, 1990; Dellino et al., 2004). Details are hard to establish in these altered and indurated deposits. At quarry III the low-angle cross-lamination in surge deposits indicates the transport direction of pyroclastic material from the north-west. Generally similar trajectories of ballistic clasts, from the west, are suggested by the asymmetrical impact sag. These features suggest a vent location for the finely laminated tuffs to, broadly, north-west of quarry III (however, the directional data come from a single point and may be inconclusive).

The tuffaceous breccias, though lithologically equivalent to the pyroclastic deposits discussed above, are distinctive in other aspects. This lithofacies is interpreted as a redeposited local tephra that fills erosional channels: gullies on a volcano slope. The gullies are NE-SW aligned, indicating the palaeoslope inclination in one of these two directions. The more massive beds of matrix-supported tuffaceous breccias resemble lahars (Vallance, 2000) and could have been deposited by volcanogenic mass flows, whereas the better sorted and laminated beds can be interpreted as deposits of ephemeral streams. Cross-lamination in the latter beds points to a westward flow direction of water and thus a westward inclination of the gullies. The gullies are found at least at two main levels in the sequence: near the base of the exposed section of bedded tuffs and within the finely laminated tuffs, close to the base of 
the overlying andesites. This may indicate alternating periods of eruptive activity and repose, the latter long enough to set stream valley incision processes in action. According to Vespermann and Schmincke (2000, p. 689), "Scoria cones in New Guinea showed significant gully erosion 5 years after eruption, in contrast to more arid regions, where erosion is negligible after thousands of years." The Lower Permian Olivětín Beds, together with the Rožmitál Succession, originated in a period of relatively arid climate, documented by the redbed-type deposits and other global to local indicators (e.g., Wojewoda and Mastalerz, 1989; McCann et al., 2008 and references cited there), so the formation of gullies at Rožmitál may have involved relatively long time intervals. On the other hand, gullies on volcano slopes may also form rapidly, e.g., during syn-eruptive events of high-intensity rainfall (Manville et al., 2009; Kereszturi and Németh, 2013, and references therein). Unfortunately, the evidence available at present from Rožmitál is not detailed enough to distinguish between long-term (years to thousands of years?) or rapid/syn-eruptive formation modes of the gullies.

\section{EMPLACEMENT OF THE ANDESITES AND THE ORIGIN OF RELATED} VOLCANICLASTIC ROCKS

The coherent andesites with associated breccias and peperites overlying the lower volcaniclastic sequence reflect a switch from early explosive eruptions to later effusive and high-level intrusive activity. In three sections at the Rožmitál quarries (logs I-N, II and IV, Fig. 3) the coherent andesites with andesite breccias can be interpreted as blocky lava flows and the origin of the andesite breccias can be linked with autoclastic processes. An erosional unconformity at the base of andesite lavas in quarry II is indicated by the stratigraphic relationships (the base of the lava overlies older deposits in the south-west, suggesting a SW-wardly inclined palaeoslope) as well as the ridges and troughs covered by lavas (interpreted as $\mathrm{N}-\mathrm{S}$ to NE-SW aligned, erosional gullies covered by lava). However, a NW-wards inclined palaeoslope can be inferred from the position of the andesite base in logs II and III-N. Possibly, the andesite flow(s) buried topographically complex terrain.

The two other sections at Rožmitál (I-S and III, Fig. 3) comprise, apart from coherent andesites and andesite breccias, abundant peperites, indicating in situ fragmentation of hot andesite lava in contact with wet, unconsolidated sediments and mixing of lava fragments with sediments (e.g., White et al., 2000; Skilling et al., 2002). Such interaction may occur during intrusion of magma into wet, unconsolidated sediment, flowage of lava over such deposits, or plunging of lava into wet, unconsolidated sediments as an invasive lava flow (e.g., Skilling et al., 2002). Invasive flows are recognized, e.g., in the Columbia River Basalt Group (Swanson and Wright, 1981). A range of factors such as the rheology of magma and host sediment, host sediment lithology and pore water content, and the volumes and rates of magma-sediment interaction influence the formation of peperites and affect resulting structures and textures (Zimanowski and Büttner, 2002; Skilling et al., 2002). At Rožmitál, the shapes of the fragments and the overall fabric of the jigsaw-textured peperites resemble blocky peperites (Busby-Spera and White, 1987) as well as in situ hyaloclastites (McPhie et al., 1993). Jigsaw textures are well recognized in such deposits (Skilling et al., 2002; Martin and Németh, 2007). The presence of undisturbed lamination in sedimentary deposits adjacent to lava fragments in peperites is less commonly reported, but similar textures have been described from the margin of an andesite sill by Kokelaar (1982: 26-27) and inter- preted as the result of the ability of magma to penetrate wet, soft sediments without their significant deformation. Thus, the jigsaw-textured peperites at Rožmitál could have formed by quench-fragmentation of andesite lava into angular blocks at contacts with wet, sandy sediment. The features described are consistent with relatively limited magma-sediment interaction. Following the emplacement and initial fragmentation of the andesite magma, with little displacement of resulting blocks, the system must have been rapidly "frozen" preventing further fragmentation and preserving the well-organized, jigsaw fabric and lamination in sediments. In contrast, the randomly textured peperites at Rožmitál bear features of both blocky and globular peperites (cf. Skilling et al., 2002; Martin and Németh, 2007) and reflect more dynamic interactions between the andesite lava and sediments. The variable shapes of the andesite blocks and the random fabric, with andesite fragments dispersed in massive to poorly laminated sediment, indicate: (1) fragmentation of andesite lava both by quenching (resulting in angular andesite fragments) as well as by dynamic mingling of andesite lava and fluidized sediment (producing irregular/lobate clasts), and (2) violent mixing of the igneous fragments and the fluidized sedimentary component.

At Rožmitál, the presence of andesite sheets associated with autoclastic breccias and associated with peperites indicates that, in the vicinity of quarry I, the andesites could have been extruded as several lobes, most of which formed "normal" block lavas while others came into contact with wet sediments either as shallow-level sills or as invasive flows. Upon the intrusive or invasive emplacement into sediments, more violent lava-sediment interactions in the outer parts of the lava bodies transformed coherent andesites and their host sediments into randomly textured peperites, whereas a more limited lava-sediment interaction in the inner parts of the lava bodies resulted either in the jigsaw-textured peperitic core (Fig. 3B, log I-S, lower part) or left the coherent core intact (Fig. 3B, log I-S, upper part). The upper coherent andesites in sections $\mathrm{I}-\mathrm{N}$ and $\mathrm{I}-\mathrm{S}$ (Fig. 3B) form a physically continuous andesite sheet and thus document lateral transition between a lava in the north and an intrusive (or invasive) sheet in the south. Due to incomplete exposure, it is difficult to judge whether the lower parts of these two sections are related by a similar transition, or represent distinctive, unrelated andesite lobes (though at similar stratigraphic levels).

A different structure is observed in the quarry III (Fig. 3). There, the abundant volcaniclastic facies, the complex transitions between variable autoclastic andesite breccias and randomly textured peperites, as well as the association of geometrically variable coherent andesite bodies, are suggestive of a near-vent region, where a transition zone between intrusive facies (the dyke and the lower coherent andesite) and extrusive facies (the upper coherent andesite) is exposed. The geometry of the lower coherent andesite in quarry III resembles a cryptodome. Lava domes and cryptodomes of even more mafic composition (basalts to trachybasalts) in vent facies of pyroclastic cones were recently documented from Nicaragua and the Chaîne des Puys (Petronis et al., 2013). The vents in the vicinity of quarry III could have fed andesite flows exposed further south, in quarry IV, and/or the lavas exposed in quarry II.

\section{A TUFF RING AT ROŽMITÁL}

As discussed above, the volcaniclastic sequence exposed at Rožmitál quarries originated in a subaerial setting during phreatomagmatic and transitional, phreatomagmatic to Strombolian eruptions with related accumulation of pyroclastic 
fall and surge deposits and minor reworking of tephra. The genesis of this sequence can be linked with the activity of a monogenetic, hydrovolcanic eruptive centre, such as a tuff ring or a tuff cone (cf. Cas and Wright, 1987; Vespermann and Schmincke, 2000; Kereszturi and Németh, 2013). These two volcano types differ in general evolutionary trends - tuff cones are initiated in subaqueous settings and later evolve into a subaerial stage, whereas tuff rings form entirely in subaerial settings; other differences include the dominant eruptive styles, related depositional processes and also the geometry of the resulting volcanic edifice (for details see Kereszturi and Németh, 2013 and references therein). The balance of evidence, in particular the lack of proof of a subaqueous volcanic stage, suggests that the Rožmitál Succession can best be linked to the activity of a tuff ring - a volcano characterized by a relatively wide central crater (a few hundred metres across) with a base located close to the pre-eruptive ground level, surrounded by a relatively low rim (tens of metres) with moderately inclined outer slopes (up to ca. $10-20^{\circ}$ ).

Most of the directional data (log II in Fig. 3) suggest, generally, a southwestwardly inclined slope of the volcano in the area of quarry II. Variable and partly inconsistent directions may be due to errors in direction estimates of some features, but may also reflect some complexities in palaeotopography and/or various sites of eruptions in a relatively wide crater. If the present low-angle dip of strata to the south-west is not much different from their original orientation, then the succession in quarry II represents either an outer, southwestern slope of the volcano (the wall facies) with a crater located north-east of quarry II, or an inner, northeastern scarp of a crater located south-west of quarry II (the upper crater facies). Transport directions of pyroclastic material in quarry III (log III-N, Fig. 3) are consistent with the latter interpretation. Possible models of the original location of the volcano and its main morphological features are illustrated in Figure 10. In either case, the tuff ring must have been several hundred metres in basal diameter, as the dips of bedding in pyroclastic rocks at quarries II and III show no systematic variation, which should mirror a curved palaeosurface of the cone. Basal diameters of up to $1 \mathrm{~km}$ are not uncommon for tuff rings (Kereszturi and Németh, 2013). A more complex morphology of the volcano, e.g., an asymmetric, breached morphology (Fig. 10A) or nested or superimposed cones (Fig. 10B), are also possible. One of the extrusive vents for the andesite lavas was likely located near the present quarry III; such a vent possibly formed inside the crater (Fig. 10A) or on the outer slope, near the base of the volcano (Fig. 10B). However, the more extensive and thicker andesite sheets to the north, both extrusive and intrusive/invasive, could have also been fed from other vents, currently not exposed.

As discussed by Németh and White (2009), the formation of a tuff ring involves modification of the local topography and hence an eruptive environment; in particular, the crater, where accumulation of water-bearing sediments is enhanced, may influence the course and style of younger eruptive episodes. The andesite lavas and shallow-level intrusions at Rožmitál could have been preferentially emplaced and trapped within the crater of the tuff ring, and the abundance of the intrusive bodies with associated peperites may reflect enhanced magma-wet sediment interactions with the crater fill. Possibly, the emplacement of the andesites shortly followed the deposition of the underlying lower volcaniclastic sequence, as a part of, essentially, the same eruptive episode. The presence of near-vent facies at Rožmitál (quarry III) supports the inferred close links between the eruption sites of the andesite tuffs and the andesite lavas.
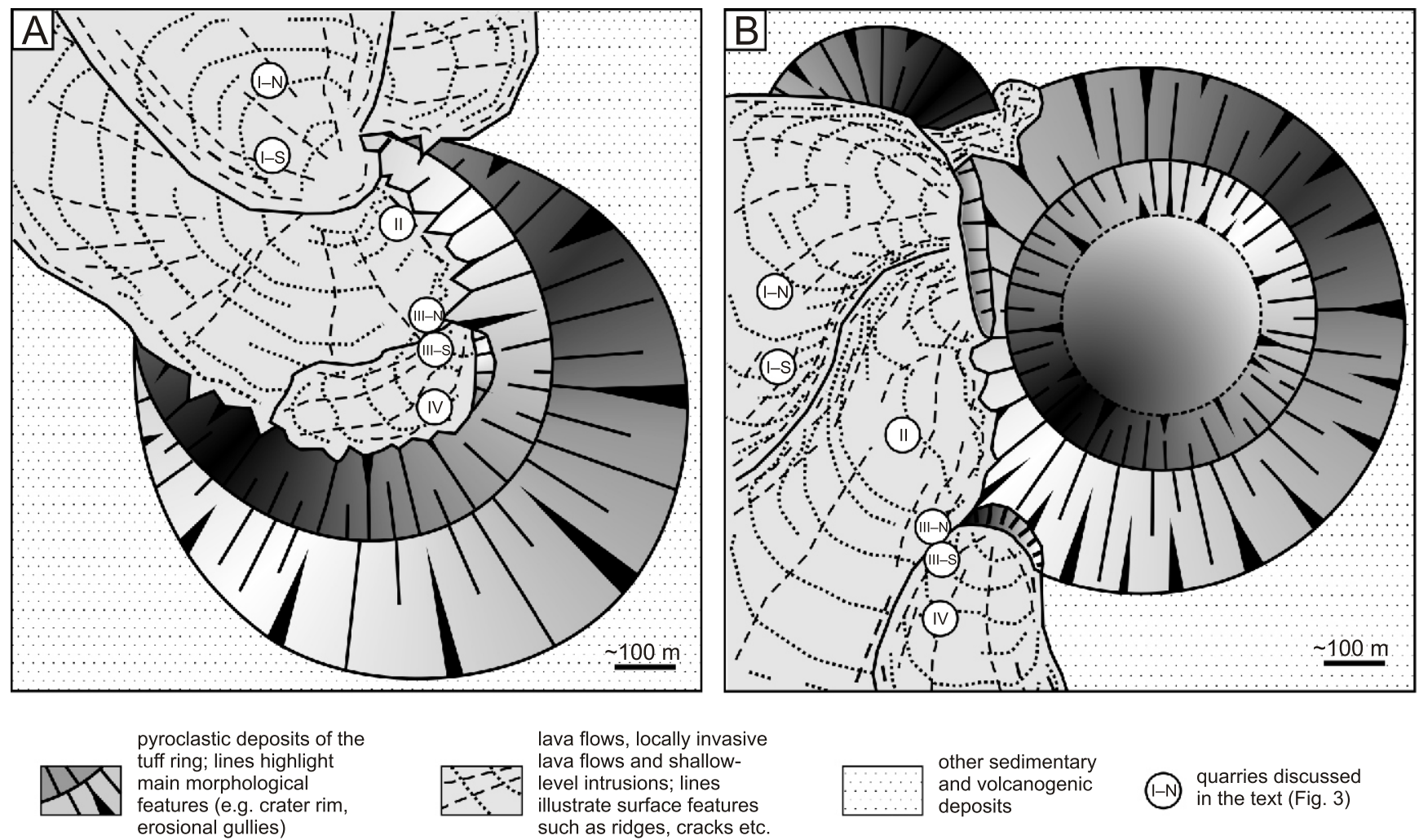

lava flows, locally invasive level intrusions; lines the

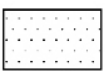

other sedimentary and volcanogenic deposits

quarries discussed in the text (Fig. 3)

Fig. 10. Tentative models illustrating the types of volcanic structures formed in the vicinity of Rožmitál in Permian times

A - a breached cone with lava flows extruded from vents in the main crater; $\mathbf{B}$ - a system of overlapping cones; the main one extruded lavas from vents on the flanks; discussion in the text 
However, one cannot exclude that the emplacement of andesites at Rožmitál occurred in a younger eruptive episode, more loosely related to the preceding, explosive volcanic stage (cf. Németh and Martin, 2007).

The ca. 700 m long section exposed along Rožmitál quarries represents the central sector and the uppermost level of a larger outcrop of andesites and related volcanogenic rocks (the Upper Šonov melaphyres of Fediuk, 1966), extending for some $8 \mathrm{~km}$ between Janovičky in the north-west and Šonov to the south-east. These volcanic rocks, together with interlayered sediments, formed along an alluvial plain, between alluvial fans in the north-west and a lake in the south-east (Tásler, 1979; Blecha, 1992). It is likely that the tuff ring inferred at Rožmitál was a part of larger field of monogenetic volcanoes, mostly of phreatomagmatic character. However, the exposure in other parts is not good and there is insufficient data at present to discuss the evolution of this field in more detail.

A major Permian volcanic event in the Intra-Sudetic Basin was the eruption of the Góry Suche Rhyolitic Tuffs, forming a distinctive marker horizon in the Lower Permian Volcanic Complex (Awdankiewicz, 1999a and references therein). The Góry Suche Rhyolitic Tuffs comprise fall and surge deposits overlain by non-welded to welded ignimbrites, with the total volume roughly estimated at a few tens of cubic kilometres. It has been suggested that the eruption of these tuffs resulted in the formation of a caldera, ca. $10 \mathrm{~km}$ in diameter, in the central part of the Intra-Sudetic Basin near Broumov (Awdankiewicz, 1999a, 2004). The Rožmitál Succession discussed in this paper is a part of the volcano-sedimentary sequence overlying the Góry Suche Rhyolitic Tuffs inside the inferred caldera. In this context, the monogenetic andesitic volcanism at Rožmitál may be considered a post-caldera volcanic stage, typical of many calderas worldwide (e.g., Lipman, 2000).

Phreatomagmatic eruptive centres, especially maar-diatreme systems, have been identified in several Permo-Carbonifeorous post-Variscan basins in Central and Western Europe (e.g., Nemec, 1981; Lorenz and Haneke, 2004; Valenta et al., 2014). Compared to tuff rings and cones, the maar-diatreme systems must have relatively large preservation potential in ancient successions, as the diatremes extend well below the palaeosurface and thus are not easily destroyed by erosion. To our knowledge, the tuff ring described in this paper from Rožmitál is the first volcano of that type identified in Late Paleozoic basins of the Bohemian Massif. This finding contributes to a better understanding of volcanic processes and of the formation of volcano-sedimentary successions in post-collisional intracontinental basins.

\section{SYNERUPTIVE SEDIMENT INCORPORATION AND CEMENTATION BY DOLOMITE IN THE PYROCLASTIC ROCKS}

The geochemical data, together with petrographic and geological observations, provide insights into processes that affected the chemical compositions of the volcaniclastic rocks from Rožmitál. The three pyroclastic rock samples differ in various ways from the coherent andesites. In the lapillistone, the $\mathrm{MgO}$ enrichment with trends towards pure dolomite composition (Fig. 9A, B) and the very high LOI (Appendix 1) can be linked with post-depositional cementation by dolomite (Fig. 7F). A similar trend, due to dolomitization, is documented also in country-rock siltstones (Čadková et al., 1985; Fig. 8A, B therein). Trace element ratios and contents in the lapillistone, partly resembling the country-rock sedimentary deposits, support also some mixing with a sedimentary component during the phreatomagmatic eruptive processes. However, the sedimentary rocks involved could have been chemically different from the arkoses and siltstones used here for comparison, and rather quartz-rich, as suggested by broken quartz fragments in the samples studied. The generally low amount of such xenocrystic quartz in the lapillistone further indicates that sediment incorporation was of relatively minor importance.

The lapilli tuff rich in accretionary lapilli differs from the coherent andesites in containing higher $\mathrm{SiO}_{2}$ (Fig. 9A, B), which can be explained by the addition of xenocrystic quartz grains from the sedimentary country rocks during phreatomagmatic eruptions. The lower contents of the light LREE (Fig. $8 \mathrm{C}$ ) and of other trace elements (Fig. 9C, D) can be also explained in terms of a quartz-rich and trace element-poor sedimentary component added to the erupted material. Arguments similar to those discussed above suggest that the sediment involved could have been partly different from samples used here for comparison. In the lapilli tuff there is also some evidence of post-emplacement cementation by dolomite (Fig. 7E), but possibly of a smaller importance in terms of the chemical influence of this process. On the other hand, the chondrite-normalized REE pattern of the lapilli tuff is not much different from that of the coherent andesites, suggesting very similar parental magmas of the lavas and tuffs.

The composition of the laminated tuff is most distinct from that of the coherent andesites. Although enrichment in $\mathrm{SiO}_{2}$ due to contamination by quartz-rich (very fine grained?) sedimentary material cannot be ruled out (Fig. 9A, B), other geochemical characteristics, in particular the higher HREE compared to the coherent andesites and the country rock sediments, suggest a more evolved composition of the parental magma of the laminated tuff. Also, the less fractionated REE pattern (lower LREE/HREE) contrasting with the pronounced Eu-anomaly suggests a different source and origin of this evolved magma.

In summary, the volcaniclastic rocks studied show abundant petrographic evidence of post-magmatic or diagenetic alteration (replacement of the original magmatic phases by post-magmatic minerals and cementation by carbonates, mostly dolomite), as well as evidence of incorporation of sedimentary components (e.g., quartz-rich sand) during the phreatomagmatic eruptive processes. The geochemical data are consistent with both these effects, although the influence of these processes was different in the various samples studied. Also, some variation in erupted magma composition can be inferred. In addition, the chemical composition of the volcaniclastic samples studied was probably affected by (1) the mobility of some components, such as silica, alkalis or the large-ion lithophile elements, during alteration and recrystallization (e.g., Rollinson, 1993), as well as by (2) mass gain or loss during the post-depositional processes (Gifkins et al., 2005). However, several of the elements used in Figures 7 and 8 (e.g., the REE, Zr, Ti, Nb, Y) are considered as relatively immobile elements, the ratios of which are not significantly affected during post-magmatic/diagenetic processes. A detailed interpretation of all the possible effects, in particular their quantification, is hampered by the limited data set presented here, and is also beyond the scope of this paper.

\section{CONCLUSION}

Although monogenetic volcanoes, such as scoria cones, maars and related phreatomagmatic eruptive centres, are common volcanic landforms on the present land surface of the 
Earth, these small volcanoes are not easily recognizable in ancient volcanic successions, such as the Permian red-beds of Central Europe. Our study of the andesitic sequence cropping out at the Rožmitál quarries, in the central part of the Intra-Sudetic Basin, show that the andesites with related volcaniclastic deposits originated during the activity of a tuff ring. This volcano had a diameter of up to ca. $1 \mathrm{~km}$ and was located close to the present Rožmitál quarries. This is possibly the first tuff ring documented in Permian deposits of the Bohemian Massif within the Central European "basin and range" volcanic province.

At Rožmitál, the bedded volcaniclastic sequence accumulated on the outer slope (wall-facies) of the tuff cone, or on the crater scarp of the cone (upper crater facies). The explosive eruptions of the volcano ranged between dominantly phreatomagmatic and, less commonly, transitional phreatomagmatic to Strombolian, the explosive activity being driven by interaction of rising andesite magma with water-bearing sediments, as well as by magmatic gases. The erupted tephra was deposited by pyroclastic fall and by pyroclastic surges. Gullies formed on the volcano slopes and tephra was redeposited by temporary streams and mass flows, gradually refilling the gullies. These processes occurred either syn-eruptively, or during longer repose periods. A switch to effusive activity resulted in the emplacement of blocky-type andesitic lava flows capping the partly eroded volcaniclastic sequence. A near-vent section in the southern part of the cone exposes a transition zone from shallow-level subvolcanic intrusions (a dyke and a sill or cryptodome) into blocky lava flows. Thicker and more extensive lava lobes and intrusive sheets were emplaced in the north, and some of the lavas possibly plunged into unconsolidated sediments, grading into invasive flows. Both the subvolcanic intrusions and the invasive flows are associated with texturally variable peperites, originating from non-explosive lava-wet sediment interactions. The andesite lavas and subvolcanic intrusions may have been preferentially emplaced within the crater of the volcano. The petrographic and bulk-rock geochemical data show that the pyroclastic deposits are mineralogically and chemically distinct from the coherent andesites, which is the combined effect of sediment incorporation during phreatomagmatic eruptions and post-depositional cementation by dolomite. Possibly, some geochemical variation in these deposits reflects also eruption of a more evolved magma of distinctive composition and origin, preceding the effusion of the andesite lavas.

Compared to other outcrops of mafic volcanic rocks in the late to post-orogenic Permo-Carboniferous intercontinental basins in the Bohemian Massif and adjacent areas, the record of volcanic processes in the andesite succession at Rožmitál is exceptionally rich. This can be linked to the proximal location of the Rožmitál quarries, close to the eruptive vents of the tuffs and the lavas. However, the sequence investigated belongs to a larger andesitic complex and further studies should reveal if the Rožmitál tuff ring was part of a more extensive monogenetic volcanic field, with several volcanic centres distributed across an alluvial plain. Our results provide insights into complex volcanic processes that contributed to the formation of the Permian volcano-sedimentary succession of the Intra-Sudetic Basin and may also help to better constrain the origin of similar deposits in other Late Paleozoic intramontane basin in Central Europe and elsewhere.

Acknowledgements. The study has been supported from the MNiSW grant N N307 133837 to HA and MA, and from the Strategic Research Plan of the Czech Geological Survey (project 321140 ) to VR and MS. The study contributed greatly from stimulating discussions during the meetings of the VENTS Project. The authorities and administration of the Rožmitál quarry are greatly acknowledged for enabling the access to the quarries. Reviews by A. Muszyński and K. Németh are highly appreciated. In particular, detailed comments and suggestions by K. Németh helped to improve the paper. T.M. Peryt is acknowledged for effective editorial work on the paper. J. Zalasiewicz language correction of the paper is highly appreciated.

\section{REFERENCES}

Agustín-Flores, J., Németh, K., Cronin, S.J., Lindsay, J.M., Kereszturi, G., Brand, B.D., Smith, I.E.M., 2014 Phreatomagmatic eruptions through unconsolidated coastal plain sequences, Maungataketake, Auckland Volcanic Field (New Zealand). Journal of Volcanology and Geothermal Research, 276: 46-63.

Awdankiewicz, M., 1997. Permian basaltic volcanism in the central part of the Intra-Sudetic Basin, SW Poland (in Polish with English summary). Acta Universitatis Wratislaviensis, 1917, Prace Geologiczno-Mineralogiczne, LV: 43-70.

Awdankiewicz, M., 1999a. Volcanism in a late Variscan intramontane trough: Carboniferous and Permian volcanic centres of the Intra-Sudetic Basin, SW Poland. Geologia Sudetica, 32: $13-47$

Awdankiewicz, M., 1999b. Volcanism in a late Variscan intramontane trough: the petrology and geochemistry of the Carboniferous and Permian volcanic rocks of the Intra-Sudetic Basin, SW Poland. Geologia Sudetica, 32: 83-111.

Awdankiewicz, M., 2004. Sedimentation, volcanism and subvolcanic intrusions in a late Palaeozoic intramontane trough (the Intra-Sudetic Basin, SW Poland). Geological Society Special Publications, 234: 5-11.

Awdankiewicz, M., Kryza, R., 2012. Late-and post-orogenic volcanism in a Variscan intramontane trough: SHRIMP zircon ages, volume estimates and geodynamic significance of Permo-Carboniferous volcanic succession of the Intra-Sudetic Basin. Mineralogia - Special Papers, 40: 65-66.

Awdankiewicz, M., Kurowski, L., Mastalerz, K., Raczyński, P., 2003. The Intra-Sudetic Basin - a record of sedimentary and volcanic processes in late- to post-orogenic tectonic setting GeoLines, 16: 165-183.

Awdankiewicz, M., Awdankiewicz, H., Anczkiewicz, R., 2013. Permian post-collisional volcanism in the Intra-Sudetic Basin new data on eruptive processes and magmatic evolution. Mineralogia - Special Papers, 41: 30.

Awdankiewicz, M., Kryza, R., Szczepara, N., 2014. Timing of post-collisional volcanism in the eastern part of the Variscan Belt: constraints from SHRIMP zircon dating of Permian rhyolites in the North-Sudetic Basin (SW Poland). Geological Magazine, 151: 611-628. 
Bas, M.J., le, Maitre, R.W., le, Streckeisen, A., Zanettin, B., 1986. A chemical classification of volcanic rocks based on the total alkali-silica diagram. Journal of Petrology, 27: 745-750.

Blecha, M., 1992. Lateral transition from alluvial fans into lacustrine environment: a depositional model of the Upper Olivetin Member (Autunian) in the Bohemian part of the intrasudetic basin (in Czech with English summary). Věstnik Českého geologického ústavu, 67: 347-362.

Bossowski, A., Sawicki, L., Wroński, J., 1981. Mapa geologiczna Polski 1:200,000. B - mapa bez utworów czwartorzędowych. Arkusz Wałbrzych (in Polish). Wyd. Geol., Warszawa.

Boynton, W.V., 1984. Cosmochemistry of the rare earth elements meteorite studies. In: Rare Earth Element Geochemistry (ed. P. Henderson): 63-114. Developments in Geochemistry. Elsevier, Amsterdam-New York.

Breitkreuz, C., Kennedy, A., 1999. Magmatic flare-up at the Carboniferous/Permian boundary in the NE German Basin revealed by SHRIMP zircon ages. Tectonophysics, 302: 307-26.

Breitkreuz, C., Kennedy, A., Geißler, M., Ehling, B.-C., Kopp, J., Muszyński, A., Protas, A., Stouge, S., 2007. Far eastern Avalonia: its chronostratigraphic structure revealed by SHRIMP zircon ages from Upper Carboniferous to Lower Permian volcanic rocks (drill cores from Germany, Poland and Denmark). GSA Special Papers, 423: 173-90.

Brož, P., Hauber, E., 2013. Hydrovolcanic tuff rings and cones as indicators for phreatomagmatic explosive eruptions on Mars. Journal of Geophysical Research: Planets, 118: 1656-1675.

Burbank, D.W., Johnson, G.D., 1983. The late Cenozoic chronologic and stratigraphic development of the Kashmir intermontane basin, Northwestern Himalaya. Palaeogeography, Palaeoclimatology, Palaeoecology, 43: 205-235.

Busby-Spera, C.J., White, J.D.L., 1987. Variation in peperite textures associated with differing host sediment properties. Bulletin of Volcanology, 49: 765-775.

Čadková, Z., Jakeš, P., Haková, M., Mrázek, P., 1985. Katalog geochemických dat základní regionální site (in Czech). Unpublished, Czech Geological Survey, Prague.

Cas, R.A.F., Wright, J.V., 1987. Volcanic Successions, Modern and Ancient: A Geological Approach to Processes, Products and Successions. Allen and Unwin, London.

Chough, S.K., Sohn Y.K., 1990. Depositional mechanics and sequences of base surges, Songaksan tuff ring, Cheju Island, Korea. Sedimentology, 36: 1115-1135.

Clarke, H., Troll, V.R., Carracedo, J.C., 2009. Phreatomagmatic to Strombolian eruptive activity of basaltic cinder cones: Montańa Los Erales, Tenerife, Canary Islands. Journal of Volcanology and Geothermal Research, 180: 225-245.

Connor, Ch.B., Conway, F.M., 2000. Basaltic Volcanic Fields. In: Encyclopedia of Volcanoes (ed. H. Sigurdson): 331-343. Academic Press.

Davidson, J., Silva S., de, 2000. Composite Volcanoes. In: Encyclopedia of Volcanoes (ed. H. Sigurdson): 663-681. Academic Press.

Dellino, P., Isaia, R., Volpe, L., la, Orsi, G., 2004. Interaction between particles transported by fallout and surge in the deposits of the Agnano-Monte Spina eruption (Campi Flegrei, Southern Italy). Journal of Volcanology and Geothermal Research, 133: 193-210.

Dziedzic, K., 1998. Genesis and evolution of Sudetic late Hercynian volcanic rocks inferred from trace element modelling. Geologia Sudetica, 31: 79-91.

Dziedzic, K., Teisseyre, A.K., 1990. The Hercynian molasse and younger deposits in the Intra-Sudetic Depression, SW Poland. Neues Jahrbuch für Geologie und Paläontologie Abhandlungen, 179: 285-305.

Fediuk, F., 1966. Melafyrový vulkanizmus na Broumovsku (in Czech). In: Základní geologický výzkum broumovského permu (ed. R. Tasler). Unpublished, Česká geologická služba, Geofond, Praha.
Fediuk, F., Schovánková, D., 1979. Svrchnopaleozoický vulkanismus vnitrosudetské pánve (in Czech). In: Geologie české části vnitrosudetské pánve (ed. R. Tásler): 145-165. Ústřední ústav geologický, Praha.

Finger, F., Roberts, M.P., Haunschmid, B., Schermaier, A., Steyrer, H.P., 1997. Variscan granitoids of central Europe: their topology, potential sources and tectonothermal relations. Mineralogy and Petrology, 61: 67-96.

Geißler, M., Breitkreuz, C., Kiersnowski, H., 2008. Late Paleozoic volcanism in the central part of the Southern Permian Basin (NE Germany, W Poland): facies distribution and volcano-topographic hiati. International Journal of Earth Sciences, 97: 973-989.

Geissler, W.H., Kämpf, H., Skácelová, Z., Plomerová, J., Babuška, V., Kind, R., 2012. Lithosphere structure of the NE Bohemian Massif (Sudetes) - a teleseismic receiver function study. Tectonophysics, 564-565: 12-37.

Gifkins, C., Herrmann, W., Large, R., 2005. Altered Volcanic Rocks. Guide to Description and Interpretation. Centre for Ore Deposits Research, University of Tasmania, Australia.

Houghton, B.F., Wilson, C.J.N., Pyle, D.M., 2000. Pyroclastic Fall Deposits. In: Encyclopedia of Volcanoes (ed. H. Sigurdson): 555-570. Academic Press.

ICS, 2013. International Chronostratigraphic Chart, v. 2013/01. International Commission on Stratigraphy, August 2012. www.stratigraphy.org, accessed at 4 January 2014.

Kereszturi, G., Németh, K., 2011. Shallow-seated controls on the evolution of the Upper Pliocene Kopasz-hegy nested monogenetic volcanic chain in the Western Pannonian Basin (Hungary). Geologica Carpathica, 62: 535-546.

Kereszturi, G., Németh, K., 2013. Monogenetic Basaltic Volcanoes: Genetic Classification, Growth, Geomorphology and Degradation. In: Updates in Volcanology - New Advances in Understanding Volcanic Systems (ed. K. Németh): InTech, 3-88. DOI: 10.5772/51387

Kodym, O., Fusán, O., Matějka, A., eds., 1967. Geological Map of Czechoslovakia 1: 500,000. West. Ústřední ústav geologický, Praha.

Kokelaar, B.P., 1982. Fluidisation of wet sediments during the emplacement and cooling of various igneous bodies. Journal of the Geological Society, 139: 21-33.

Kryza, R., Awdankiewicz, M., 2012. Ambiguous geological position of Carboniferous rhyodacites in the Intra-Sudetic Basin (SW Poland) clarified by SHRIMP zircon ages. Geological Quarterly, 56 (1): 55-66.

Lipman, P.W., 2000. Calderas. In: Encyclopedia of Volcanoes (ed H. Sigurdson): 643-662. Academic Press.

Lorenz, V., Haneke, J., 2004. Relationship between diatremes dykes, sills, laccoliths, intrusive-extrusive domes, lava flows, and tephra deposits with unconsolidated water-saturated sediments in the late-Variscan Saar-Nahe-Basin, SW Germany. Geological Society Special Publications, 234: 75-124

Lorenz, V., Nicholls, L.A., 1976. The Permo-Carboniferous Basin and Range province of Europe, an application of plate tectonics. In: The Continental Permian in Central, West and South Europe (ed. H. Falke): 313-342. Reidel, Dordrecht.

Manville, V., Németh, K., Kano, K., 2009. Source to sink: a review of three decades of progress in the understanding of volcaniclastic processes, deposits, and hazards. Sedimentary Geology, 220: 136-161

Martin, U. and Németh, K., 2007. Blocky versus fluidal peperite textures developed in volcanic conduits, vents and crater lakes of phreatomagmatic volcanoes in Mio/Pliocene volcanic fields of Western Hungary. Journal of Volcanology and Geothermal Research, 159: 164-178.

Mastalerz, K., Prouza, V., 1995. Development of the Intra-Sudetic Basin during Carboniferous and Permian. In: Sedimentary Record of the Variscan Orogeny and Climate - Intra-Sudetic Basin, Poland and Czech Republic (eds. K. Mastalerz, V. Prouza, L. Kurowski, A. Bossowski, A. Ihnatowicz and G. Nowak): 5-15. 
Guide to Excursion B1. XIII International Congress on Carboniferous-Permian. August 28-September 2, 1995, Kraków, Poland.

Mazur, S., Aleksandrowski, P., Kryza, R., Oberc-Dziedzic, T., 2006. The Variscan Orogen in Poland. Geological Quarterly, $\mathbf{5 0}$ (1): 89-118.

Mazur, S., Aleksandrowski, P., Turniak, K., Awdankiewicz, M., 2007. Geology, tectonic evolution and Late Palaeozoic magmatism of Sudetes - an overview. Archivum Mineralogiae Monograph, 1: 59-87.

McCann, T., Pascal, C., Timmerman, M.J.P., Krzywiec, P. Lopez-Gomez, J., Wetzel, A., Krawczyk, C.M., Rieke, H., Lamarche, J., 2006. Post-Variscan (end Carboniferous - Early Permian) basin evolution in Western and Central Europe. Geological Society Memoirs, 32: 355-388.

McCann, T., Kiersnowski, H., Krainer, K., Vozárová, A., Peryt, T. Oplustil, S., Stollhofen, H., Schneider, J., Wetzel, A., Boulvain, F., Dusar, M., Török, Á., Hass, J., Tait, J., Körner, F., 2008. Permian. In: The Geology of Central Europe, 1: Precambrian and Palaeozoic (ed. T. McCann): 531-599. Geological Society, London.

McPhie, J., Doyle, M., Allen, R., 1993. Volcanic Textures. A Guide to the Interpretation of Textures in Volcanic Rocks. CODES, Tasmania.

Menard, G., Molnar, P., 1988. Collapse of a Hercynian Tibetan Plateau into a Late Palaeozoic European Basin and Range province. Nature, 334: 235-237.

Milewicz, J., Szałamacha, J., Szałamacha, M., 1989. Mapa geologiczna Polski 1:200,000. B - mapa bez utworów czwartorzędowych. Arkusz Jelenia Góra (in Polish). Wyd. Geol., Warszawa.

Morrisey, M., Zimanowski, B., Wohletz, K., Buettner R., 2000. Phreatomagmatic fragmentation. In: Encyclopedia of Volcanoes (ed. H. Sigurdson): 431-445. Academic Press.

Nemec, W., 1981. Problem of the origin and age of volcaniclastic rocks along the eastern margin of Wałbrzych Coal-Basin (in Polish with English summary). In: Problemy Wulkanizmu Hercyńskiego w Sudetach Środkowych. Materiały Konferencji Terenowej, Ziemia Wałbrzyska, 30-31 maja 1981 (ed. K. Dziedzic): 92-105. Wydawnictwa Uniwersytetu Wrocławskiego.

Nemec, W., Porebski S., Teisseyre, A.K., 1982. Explanatory notes to the lithotectonic molasse profile of the Intra-Sudetic Basin Polish Part (Sudety Mts., Carboniferous-Permian). Veröffentlichung des Zentralinstituts für Physik der Erde AdW DDR, Potsdam, 66: 267-277.

Németh, K., 2010. Monogenetic volcanic fields: Origin, sedimentary record, and relationship with polygenetic volcanism. GSA Special Paper, 470: 43-66.

Németh, K., Martin, U., 2007. Shallow sill and dyke complex in western Hungary as a possible feeding system of phreatomagmatic volcanoes in "soft-rock" environment. Journal of Volcanology and Geothermal Research, 159: 138-152.

Németh, K., Risso, C., Nullo, F., Smith, I.E.M., Pécskay, Z., 2012. Facies architecture of an isolated long-lived, nested polygenetic silicic tuff ring erupted in a braided river system: the Los Loros volcano, Mendoza, Argentina. Journal of Volcanology and Geothermal Research, 239-240: 33-48.

Oberc-Dziedzic, T., Kryza, R., Pin, C., Madej, S., 2013a. Sequential granite emplacement: a structural study of the late-Variscan Strzelin intrusion, SW Poland. International Journal of Earth Sciences, 102: 1289-1304.

Oberc-Dziedzic, T., Kryza. R., Pin, C., Madej, S., 2013b. Variscan granitoid plutonism in the Strzelin Massif (SW Poland): petrology and age of the Strzelin granites. Geological Quarterly, $\mathbf{5 7}$ (2): $269-288$

Pearce, J.A. 1996. A user's guide to basalt discrimination diagrams. Geological Association of Canada, Short Course Notes, 12: $79-113$
Petronis, M., Delcamp, A., Wyk de Vries, B., van, 2013. Magma emplacement into the Lemptégy scoria cone (Chaîne Des Puys, France) explored with structural, anisotropy of magnetic susceptibility, and Paleomagnetic data. Bulletin of Volcanology, 75: 753. DOI 10.1007/s00445-013-0753-y

Prouza, V., 1988. Geologická mapa ČR, List 04-32 Broumov (in Czech). Praha (ÚUG).

Sawicki, L., 1988. Mapa geologiczna Polski 1:200,000. B - mapa bez utworów czwartorzędowych. Arkusz Kłodzko (in Polish). Wyd. Geol., Warszawa.

Rollinson, H.R., 1993. Using Geochemical Data: Evaluation, Presentation, Interpretation. Longman Scientific and Technical.

Seghedi, I., 2011. Permian rhyolitic volcanism, changing from subaqueous to subaerial in post-Variscan intracontinental Sirinia Basin (SW Romania-Eastern Europe). Journal of Volcanology and Geothermal Research, 201: 312-324.

Skilling, I.P., White, D.L., Mcphie, J., 2002. Peperite: a review of magma-sediment mingling. Journal of Volcanology and Geothermal Research, 114: 1-17.

Štamberg, S., Zajíc, J., 2008. Carboniferous and Permian faunas and their occurrence in the limnic basins of the Czech Republic. Museum of Eastern Bohemia at Hradec Králové.

Stárková, M., Rapprich, V., Breitkreuz, C., 2011. Variable eruptive styles in an ancient monogenetic volcanic field: examples from the Permian Levín Volcanic Field (Krkonoše Piedmont Basin, Bohemian Massif). Journal of Geosciences, 56: 163-180.

Swanson, D.A., Wright, T.L., 1981. Guide to geologic field trip between Lewiston, Idaho and Kimberly, Oregon, emphasizing the Columbia River Basalt Group. In: Guides to some volcanic terranes in Washington, Idaho, Oregon, and Northern California (eds. D.A. Johnston and J. Donnelly-Nolan). Geological Survey Circular, http://www.nps.gov/history/history/online_books/geology/publications/circ/838/ (accessed 2014-03-27)

Tait, M.A., Cas, R.A.F., Viramonte, J.G., 2009. The origin of an unusual tuff ring of perlitic rhyolite pyroclasts: the last explosive phase of the Ramadas Volcanic Centre, Andean Puna, Salta, NW Argentina. Journal of Volcanology and Geothermal Research, 183: 1-16.

Takada, A., 1994. The influence of regional stress and magmatic input on styles of monogenetic and polygenetic volcanism. Journal of Geophysical Research, 99: 13563-13573.

Tásler, R., ed., 1979. Geology of the Bohemian part of the Intra-Sudetic Basin (in Czech with English summary). Ústředni Ústav Geologický, Praha.

Timmerman, M.J., 2008. Palaeozoic magmatism. In: The Geology of Central Europe, 1: Precambrian and Palaeozoic (ed. T. McCann): 665-48. The Geological Society, London.

Ulrych, J., Fediuk, F., Lang, M., Martinec, P., 2004. Late Palaeozoic volcanic rocks of the Intra-Sudetic Basin, Bohemian Massif: petrological and geochemical characteristics. Chemie der Erde - Geochemistry, 64: 127-153.

Ulrych, J., Pešek, J., Štepánková-Svobodová, J., Bosák, P., Lloyd, F.E., Seckendorff, V., von, Langa, M., Novák, J.K., 2006. Permo-Carboniferous volcanism in late Variscan continental basins of the Bohemian Massif (Czech Republic): geochemical characteristics. Chemie der Erde - Geochemistry, 66: $37-56$

Valenta, J., Rapprich, V., Stárková, M., Skácelová, Z., Fojtíková, L., Staněk, F., Balek J., 2014. Problems and challenges in detection of pre-Mesozoic maar volcanoes: example from the Principálek Volcano in the Permian Krkonoše Piedmont Basin. Journal of Geosciences, 59: 169-181.

Valentine, G.A., Fisher, R.V., 2000. Pyroclastic surges and blasts. In: Encyclopedia of Volcanoes (ed. H. Sigurdson): 571-580. Academic Press.

Vallance, J.W., 2000. Lahars. In: Encyclopedia of Volcanoes (ed. H. Sigurdson): 601-616. Academic Press. 
Vespermann, D., Schmincke, H.-U., 2000. Scoria cones and tuff rings. In: Encyclopedia of Volcanoes (ed. H. Sigurdson): 683-694. Academic Press.

White, J.D.L., McPhie, J., Skilling, I., 2000. Peperite: a useful genetic term. Bulletin of Volcanology, 62: 65-66.

Wilson, M., Neumann, E.-R., Davies, G.R., Timmerman, M.J., Heeremans, M., Larsen, B.T., eds., 2004. Permo-Carboniferous Magmatism and Rifting in Europe. Geological Society Special Publications, 223.
Wojewoda, J., Mastalerz, K., 1989. Climate evolution, allo- and autocyclity of sedimentation: an example from the Permo-Carboniferous continental deposits of the Sudetes (in Polish with English summary). Przegląd Geologiczny, 37: 173-180.

Ziegler, P.A., Dèzes, P., 2006. Crustal evolution of Western and Central Europe. Geological Society Memoirs, 32: 43-56.

Zimanowski, B., Bottner, R., 2002. Dynamic mingling of magma and liquified sediments. Journal of Volcanology and Geothermal Research, 114: 37-44. 